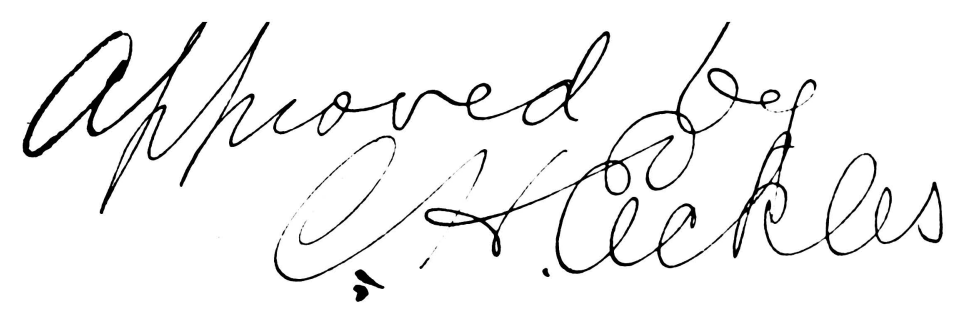

THE PURE MILK PROBLEM OF THE SMALL TOWN.

A SURVEY AND MOVEMINT FOR IMPROVING TYF VIIK SUPPIY OF ST. CHAFIES, NOO.

by

i.

Percy Werner, Jr., B. S. A.

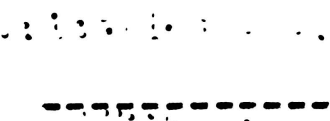

.

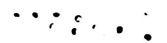

SUBMITTED IN PAKTIAL FULFILIMENT OF THE REQUIRFNINTS FOR TIE DEGREE OF MASTFR OF ARTS

in the

GRADUATE SC.HOOL

of the

UNIVFRSITY OF NISSOURI 
378.7071

XW495

Table of contents.

Part I.

Page

I. Introductory Discussion of City Milk Supply.....I

A. Sanitary Control of Milk--A Public Problem..2

B. Efforts to Improve Milk Supplies--H1storical....3

1. Chemical Standards.

$\ldots 3$

2. Inspection.

3. Bacterial Standards................

4. Pasteurization.

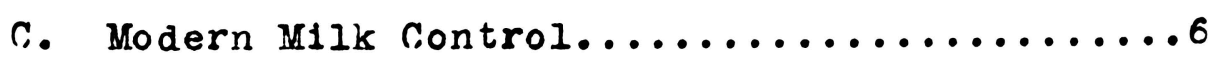

1. Grading........................

2. Private Efforts at Milk Improvement....?

D. Milk Supply of the Small Town............

E. Work of Agricultural Experiment Stations and Colleges in Milk Control Work..10

F. Scope of Investigation by the Writer......12

II. Plan of Present Investigation...............

III. Observation........................

A. Condition of the Milk.

.16

B. Preliminary Survey.

.25

c. Conditions as Found on the Fanns.........28

1. Description of Dalries...............28

D. Resume of Conditions ..................33

$$
149643^{\circ 9}
$$


Table of Contents (Continued).

Page

IV. Causes..............................

A. Immediate causes...................... 35

1. High Bacterial Count..................

2. Variation in Per Cent of Fat..........36

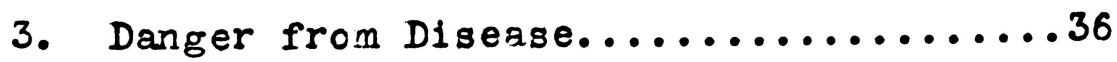

B. Underlying Causes of the Use of Faulty Methods...37

1. Personal causes......................

2. Economic Causes.......................

3. Social Causes..................42

V. Efforts for Improvement--Results obtained.....43

A. Introduction--Agencies at Hand.........43

B. Efforts for Improvement..............44

1. Removal of Personal Causes..........45

a. Ignorance of Dalrymen...........45

b. Unf1t Da1rymen...............45

c. Destructive Competition and

$$
\text { Jealousy...47 }
$$

2. Removal of Economlc Causes...........49

3. Removal of Social Causes.............5I 


\section{Table of Contents (Continued).}

Page

VI. Discussion of Results.................69

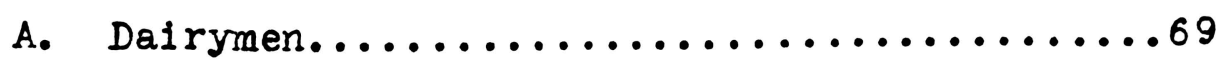

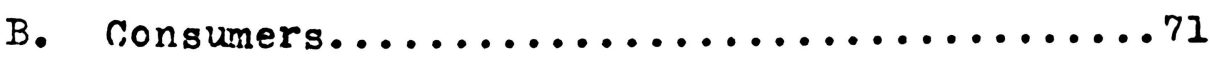

c. Public Officials and Business Men..........7

D. Milk of St. Charles..................

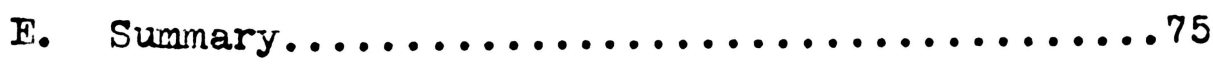

F. Part of Agricultural colleges and Experiment Stations in Milk Control

work..........................

Part II.

VII. Control--.......................78

A. Application of Breed Method of Counting Bacteria........78

B. Historical...................... 80

c. Experimental Work..................86

D. Discussion of Results...............91

VIII. BIbllography...................994 
PART I.

Survey and Movement for Improvement. 
I. INTRODUCTORY DISCUSSION OF THE CITY MIIK SUPPLY.

An abundant supply of clean safe milk is of growing importance to every community. With an average dally consumption of 0.6 pint per person, over 1,600,000,000 gallons cf market milk must be distributed annually in upwards of 2400 cities of the United States having a population exceeding 2500. Much of this milk is used for infart feeding. It is easily digested, cheap and of especial value in the nutrition of children because of the accessories to grourth in. which it is rich. $(2 \& 3)$ The problem of securing pure milk for bottle fed bables is of greater importance today because of the observations of physicians and others who have collected data on the subject, which indicates that "The medern mcther is growing more and more unable to nurse her chfld at her breast." (4)

Notwithstarding the value of milk as a food and 1 ts need ir the diet, there has arisen in the public mind a distrust of milk, since science has so repeatedly been compelled to point to the milk supply as a mcst important cause of sickness and death, especially among infants. Nilk, when fed in a filthy 
and partially decomposed state unquesticnably is a serious cause of digestive troubles. By carrying germs of specific diseases as the typhotd and tubercle bacilli, milk has also been an important factor in the spread of disease. The Immense saving of life brought abcut by the work of Nathan straug(5) and others interested in establishing pure milk depcts in the larger clties, has clearly shown that the most harmful effects produced by milk result from feeding dirty, partially spoiled milk. The findings of the British Royal Commission on the Relation of Human and Animal Diseased $(6)$ and the work of numberless scientists makes certain the alarming connection between the milk of tubercular animals and the spread of tuberculosis. The long list of typhold fever, diphtherla, and scarlet fever epidemics tabulated by Trask (7) indicate the existence and importance of the spread of these diseases by infected milk.

Sanitary Control of Milk -- A Public Problem.

It is because of this need for pure milk and the difficulties entering into the problem of securing It for the modern city, that the milk supply has become an Important public problem. The problem is the most serlous in towns and municipalities supplied with milk which is produced at a considerable distance and which 
necessarily passes thru a number of hands. The importance of the problem for each town depends largely on the size of the town. The milk of the larger town comes as a rule from many farms, at considerable distance, passes thru many hands, so that fixing responsibility is difficult, especially when the milk reaches the consumer, when from 24 to 36 hours old. The milk of the small town is produced by a few dalrymen who deliver it direct to the consumer when only 4 to 18 hours old. EFFORTS TO INPROVF MILK SUPPLIFS -- HISTORICAL.

Farly efforts to 1mprove the milk supply consisted in efforts to prevent the adulteration of foods including milk, end in the private utterances directed againgt the use of bad milk such as that of R. M. Hartly, who in 1843 published a book, "The row and the Dairy" in which he pointed out the relationship between irfant mortality and the use of "Bwillnmilk.

\section{Chemical Standards:-}

This protest and the laws which followed it dealt with the chemical composition of the milk alone. The earliest laws affectirg milk were, therefore, these directed against adulteration and misbranding of 
food, including milk. Control of the chemical compositicn of milk by means of standards became commen, every state in the Union now having legal standards for dalry products. As the importance of bacteria to the quality of milk began to be realized, rules and regulations were adopted by cities and towns attemptirg to regulate the santary producticn and distribution of milk; such as tuberculin testing of herds, use of certain equipment and methods, and the applicaticn of refrigeration to the milk during storage and transit.

Inspection:-

Inspection of dairies came as a natural corollary of such regulations. In order to facilitate and make more effective this inspection, Dr. Woodward in 1904 made the first use of a score card in the inspecticn of dalries in the District of Columbia. (9) This lead to the drawirg up of the United States Department of Agriculture, Bureau of Animal Industry Score Card in 1906, which card has had such wide use in municipal irspecticn work. The use of the score card has been written into law in numerous instances. Dalries supplying a particular comuntty are in some cases required to come up to a certain score. 
Bacterial Standards:-

In judgirg the saritary quality of milk, the bacterial count has been widely used. The immediate causes of excepticnally hich bacterial counts may be due to one or all of four things: (I) high initial contamination of milk by the use cf dirty cows, dirty utensils and dirty men; (2) keeping milk at high temperatures durirg storage and delivery; (3) holding milk for a lone pericd; (4) sericus contamination during delivery. Racterial standarda were added to chemical standards by many cities, until in 1914 there were 145 cities in the United states, of 10,000 inhabitants or over, havirg a bacteriological requirement for milk and cream. (10)

Pasteurization:-

The difficulties of securirg a supply of milk whlch could be guaranteed to be free from disease germs and the difficulty of keeping milk sweet from the time it left the farm until it reaches the consumer, sometimes 200 to 400 miles away, has brought forward many advocates of pasteurization of market milk. This process, which was first applied to milk in Denmark, for the purpose of preventing the spread of disease to farm animals by skimmilk from creameries and factories, has been made compulsory by many cities for a part of the milk supply at least. 
MODERN MILK CONTROL.

\section{Grading:-}

The trend of milk improvement in recent years has been away from the lines of force, leaning rather toward improvement thru education of the producer and consumer in the value of clean milk with the payment for it on the basis of its sanitary and chemical quality. Systems of buying milk on this basis have been reccmended as the most effective way of securing the sanitary production cf milk. One such is that of grading milk into several classes with different sanitary standards which sell for varying prices. Such a method was advanced in 1900 by the United States Department of Agriculture.(II) This plan suggested that milk be put into three grades: certified, inspected, and pasteurized. Such a grading could not be made ir all cities, however, because certified milk commissions cannot secure support in many of the smaller towns. A more practical system of grading milk into three grades, based on the number of bacteria present, is in use in many cities.

of recent years Dr. North of New York has been attempting to mcld public opinion into a conception of the proper use of a number of these methods in the larger cities. (12) He would have milk distributirg companies buy from the farmers on the basis of the bacterial count and butter fat test, with a premium for tuberculin 
testing. Inspection of dairies would be Ilmited to those dairies requiring help as shown by their high bacterial counts. Such companies would operate a bottling and pasteurizing plant in the country dairy districts where the cans and the buckets of the dalrymen can be washed, sterilized and dried; and the milk can be tested, bottled and shipped. Entirely aside from any dealings with the producers, but as a health measure, he would compel the pasteurization of all milk at these stations. Practical results(13) of such a system have shown with what ease an average set of dalrymen can be made to produce clean milk where the proper stimulus is applied.

Private Efforts at Milk Improvement:-

A discusition of the dairy reform movenents would not be complete without mention of the work of Nathan Straus in establishing infant milk depots, and of the Medical Milk Commissions in the supervision of the production of Certifled milk, whlch has done so much toward raising the standards of clean milk production, especially in the larger cities. What the milk depot has done for the poor of the large clty, the Medical Milk Commissions have done for the well-to-do. Ever since the establishment of the first certified dalry farm in Essex County, New Jersey, by Dr. H. L. Cołt, in 1893, the country has had a standard for the sanitary production and distribution of milk, which can hardly be 
excelled. (14) Most of the large cities of the United States support one or more of these certified farms. (15) of the two private efforts to better the milk supply: nanely, the establishment of infant milk depots by Nathan Straus, and the Certified dairies by the Medical Milk Commissions, the forner is the more signtficant. The results obtalned from these depots clearly show that good milk can be made absolutely safe by proper pasteurization without interfering with the digestibility or the food value of the milk or the accessories to growth which it contains. (16) on the other hand, there is still so much danger of the spread of disease thru raw milk, even when the sources of supply are under as careful supervision as are the certified dairies, (15) that there is considerable doubt as to the absolute safety of any raw milk.

MILK SUPPLY OF THE SMALL TOWN.

The problem of securing pure milk is greater now, and probably always will be greater in the large city than in the small town. Much more headway has, howerer, been made in the large city, as the above review will indicate. Mcst cities in the middle west, of 15,000 population or under, have no contral over their milk supply whatsoever. The education of the consumer in the use of and demand for clean milk has been the maln method 
of improvement.

There is need for considerable study of the exact importance of the milk problem of the small town and of the proper means of remedying bad conditions. In this work the agricultural colleges should be of considerable ald.

The control of the milk supply of the small town offers difficulties which are peculiar to itself, and which do not exist in the larger municipalities. First, the very smallness of the supply makes the average methods of control of the large supply uneconomical and Impractical in the town of 15,000 or under. Second, the type of public office holders, the inefficient organization of municipal government, and the low municipal income of the average sinall town, tend to reduce the efficiency of public control problems. Third, the lack of sufficient intelligent leadership anong the citizens to push thru and keep alive an effort to protect the consumers of milk, prevents the successful continuance of efforts at control.

On the other hand, there are factors which tend to make the pure milk problem of the small town of less Importance than that of the large city. First, the milk is produced within a radius of a very few miles of the consumer, which enables the producer to deliver his product within a few hours after production; second, the nearness to the market resulting in the delivery of the 
milk by the producer direct, enables the consumers to choose the source of their milk. Third, infection of any one source does nct have the far reaching effects which it has in the larger towns, where milk from hundreds of farns is mixed together at a central distributing plant before delivery.

\section{WORK OF THE AGRICULTURAL}

EXPERIMENT STATIONS AND COLLFGES IN MILK CONTROL TORK.

No attempt will here be made to review the endless amount cf work carried on by health boards and private individuals in improving the public milk supply. The actual improrement and control of milk supplies has been almost exclusively carried on by such boards. The work of the colleges and experiment stations in this direction is of Immediate interest, since part of the purpose of this investigation is to determine to what extent these institutions may enter into milk control problems. While they are interested in the protection of the consumer of milk, the maln justification for the expenditure of time and money in milk control problens is the adrantageous effects it has on the dairy industry. Their work has consisted mainly of surveys of milk supplies without any crganized effort at improvement or control. Trueman of Illinols in 1905 and 1906 made 
an extensive investigation into the condition of the milk of Chicago and twenty-six other towns. (17) He made butter fat and sediment tests on milk collected, but did not make bacterial analyses. Such work as his and that of the Bureau of Animal Industry of the United States Department of Agriculture, which has made a number of surveys of milk supplies in various parts of the country, $(18,19,20,21)$ merely serve to indicate the need of milk reform and contrcl. Bitting of Indiana (22) in 1901 reports a sanitary survey of the milk supply of Lafayette, Indiana, with general suggestions for the improvement of market milk. Hammer and Hauser of Iowa, (23) report in 1916 results of a survey of a number of Iowa cities, which leads them to the conclusion that there is a real milk problem existirg in the small towns of Iowa. Allen of Kentucky in 1908 reports a somewhat similar survey of Louisville, $\mathrm{Ky} \cdot(40)$

The first attempt of an Experiment station to instigate a reform and supervise control of a city milk supply was made by Harding (24) whlle at the New York Fxperiment Station at Geneva. It was the purpose of his study, "To find a way by which the small city with its limited facilities may obtain as sanitary a milk supply as the largest cities with their technically trained advisors and expensive equipment." 
By a regular system of inspection of dalries, with publiclty, and payment based on qualfty, the Geneva milk supply was ereatly tmproved during a period of three years. The work of this improvement was carried on by the local board of health, under the supervision of the Experiment Station.

In Bulletin No. 363 of the same station, (25) further notes on the Geneva supply showed a marked change for the worse during the years of 1911 and 1912. An inefficient milk inspection, which resulted in fallure to pay for the milk on the basis of quality, was responsible for this lowering of the quality of the milk supply.

SCOPE OF INVESTIGATION BY TFF WRITFR.

The present investigation will be confined to a single town in the hope that concentrated study of the conditions in one communty will lead to a method of improvement and control which, if successful, will make easier the develcpment of similar control in other parts of the state. General state surveys have served the1r purpose in awakening the public to a realization of the importance of the milk problem in the small towns, but real improvement and control can come only thru concentrated effort in individual comunities. 
Town Chosen:-

St. Charles, Mo., a town of approximately ten thousand population, situated in st. Charles County, twenty miles from st. Louis, was selected for the experiment. This particular town was chosen because its milk supply was known to be in need of improvement, and because of the convenience with which it could be reached. A county farm advisor is situated in the town, who, it was thought, could be of help. The high school chemlstry laboratory offered an ideal place for making the labcratory tests of the milk. This room was equipped with running water and gas, and was centrally located. The equipment necessary to make the tests was supplied by the dairy bacteriology labcratory of the Univereity. 


\section{PLAN OF PRESENT INVESTIGATION.}

The object of this investigation was to

study:

1. The condition of the milk supply of an average small town;

2. The underlying causes of the conditions which exist;

3. A method for the imorovement and control of such a milk supply, the execution of which would be within the proper functions of representatives of the state colleges and experiment stations.

Before a method of Improvement or control for any milk supply can be determined upon, the conditions of the supply tc be improved have first to be studied. The conditions are naturally of two sorts: (1) the quality of the milk itself as delivered to the consumer, and (2) the conditions surrounding its production and distribution which determine its composition and sanitary qualities.

Vith these ideas in mind, it was planned to make a survey of the milk supply cf the city selected, and to study the milk as delivered to the consumers, and the conditions under which it was produced.

The milk samples taken from the delivery wagons were to be exanined according to usual 
laboratory methods for the following:

(1) Number of bacteria.

(2) Per cent fat, solids not fat, and water.

(3) Temperature at which delivered.

The number of bacteria was to be taken as an indication of the cleanliness observed in the production, and the care in handing during stcrage and delivery. The chemical tests indicate presence of adulteration and skimming.

The conditions on the farns to be noted were general santtary conditions and the methods used in the production of the milk, such as cleaning of cows and stables, condition and care of the utensils, care of milk during storage and delivery, use of tuberculin tested cows, protection of the milk from disease contamination of human origin. A careful study of these conditions, it is belleved, will show where and to what extent improvement is needed. 


\section{OBSERVATIONS.}

\section{CONDITIONS OF THE MIIK.}

The following tables show the results of the tests during the months of June, July, August, October, and January. Samples of "loose" milk were collected from the milk wagons in sterile milk bottles. Bottled milk was sampled by taking one of the original containers. The temperature of the milk was taken at the time it was recelved from the dairymen. The samples were iced within a half hour after collection and kept below 50 degrees Fahrenhelt until tests were made, which was not later than five hours after collection. Samples were collected from all dairymen whose wagons could be located during the morning delivery.

\# A trade name for milk sold from cans and not from bottles. 
Table I.

Analyses for June.

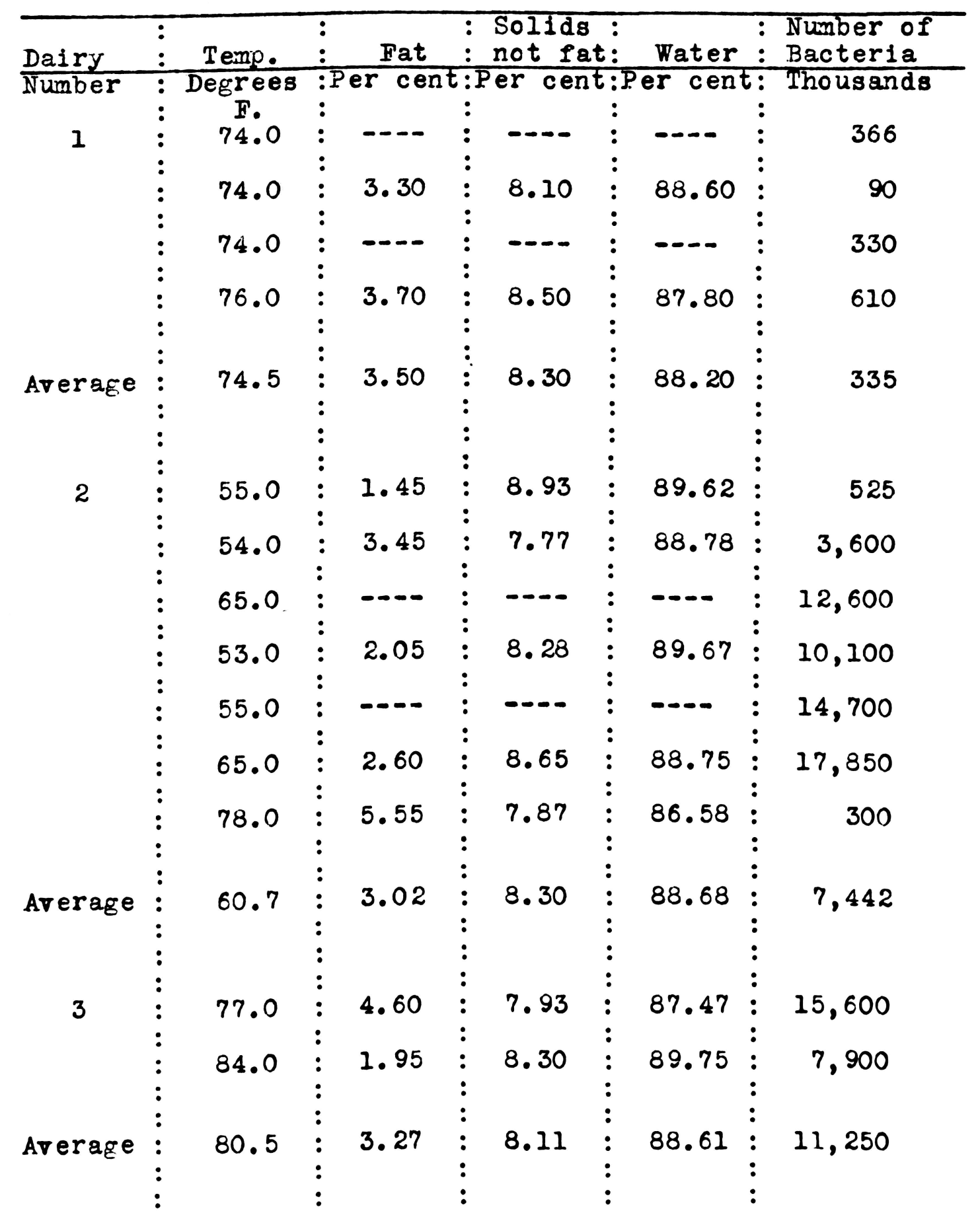


Table I. (Continued)

Analyses for June.

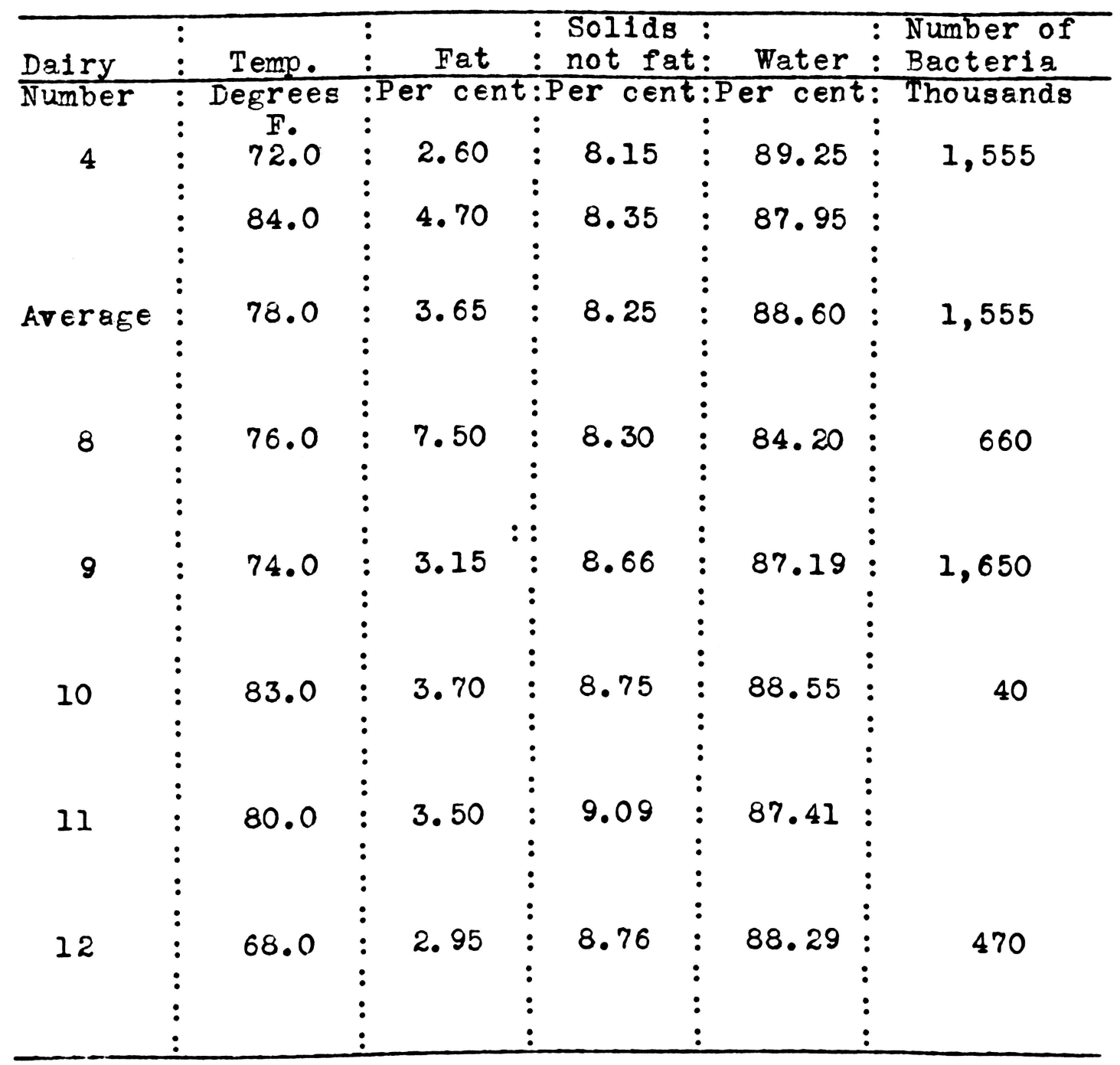


Table II.

Analyses for July.

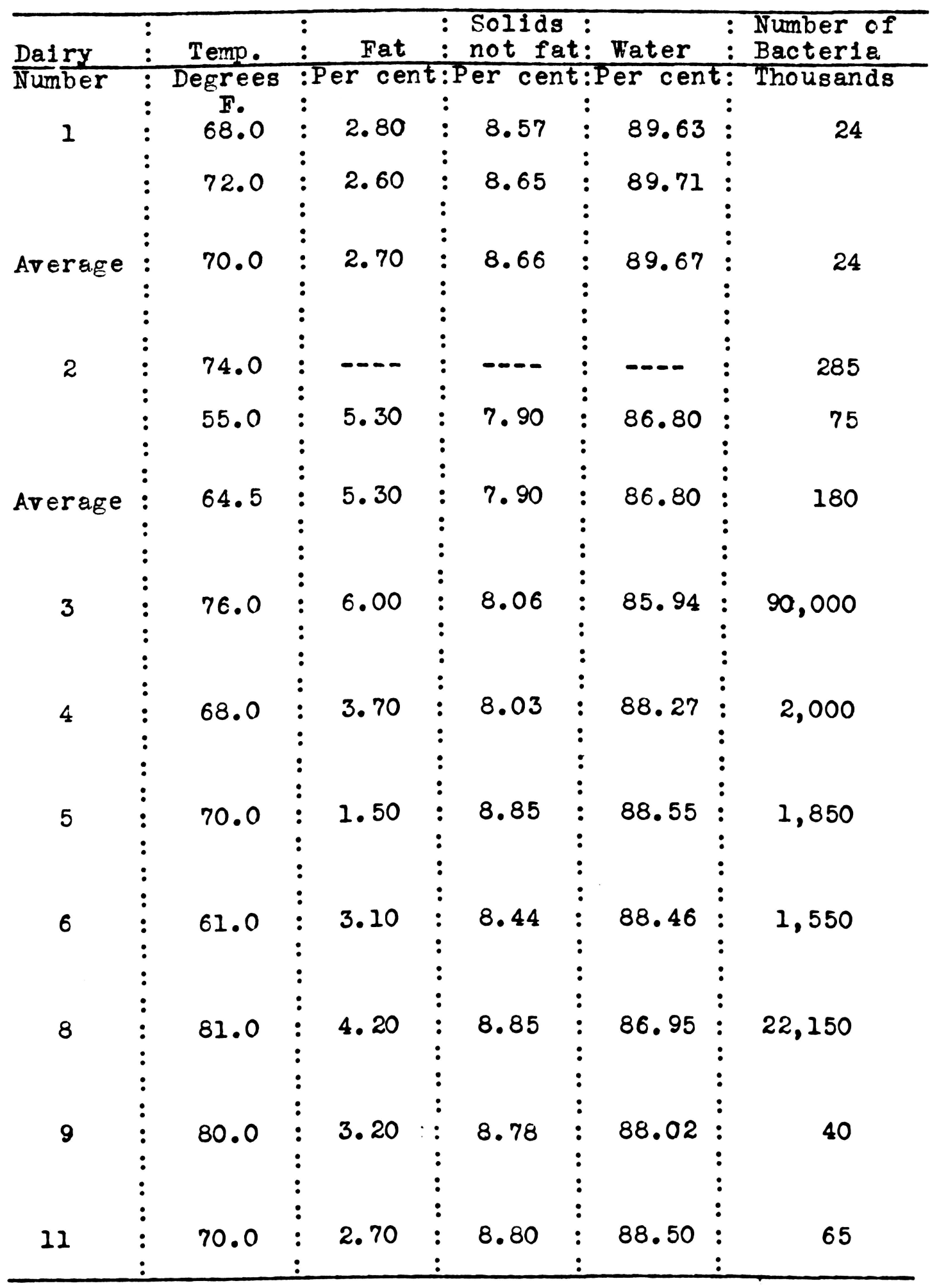


Table III.

Analyses for August.

\begin{tabular}{|c|c|c|c|c|c|c|c|c|c|c|}
\hline Dairy & $:$ & Temp. & $:$ & Fat & : & $\begin{array}{l}\text { Solids } \\
\text { not fa }\end{array}$ & $:$ & Water & $:$ & $\begin{array}{l}\text { Number of } \\
\text { Bacteria }\end{array}$ \\
\hline Number & : & $\begin{array}{c}\text { Degrees } \\
\text { F. }\end{array}$ & $\overline{: P}$ & er cen & $\begin{array}{c}t: P \\
:\end{array}$ & er cen & $\begin{array}{c}t: P \\
:\end{array}$ & er cent & : & Thousands \\
\hline \multirow[t]{4}{*}{1} & $:$ & & : & 4.00 & $:$ & 8.66 & : & 87.34 & $:$ & 525 \\
\hline & $:$ & & : & & $:$ & & $:$ & & $:$ & \\
\hline & $\begin{array}{l}: \\
:\end{array}$ & & : & 3.40 & $\begin{array}{l}: \\
:\end{array}$ & 8.54 & $\begin{array}{l}\vdots \\
:\end{array}$ & 88.00 & $:$ & 2,000 \\
\hline & : & & : & & : & & : & & $:$ & \\
\hline \multirow[t]{3}{*}{ Average } & $:$ & & : & 3.70 & $:$ & 8.65 & $:$ & 87.70 & $:$ & 1,262 \\
\hline & : & & : & & : & & $:$ & & : & \\
\hline & : & & : & & $:$ & & : & & $:$ & \\
\hline \multirow[t]{4}{*}{2} & $:$ & & : & 4.55 & $\vdots$ & 6.62 & $\begin{array}{l}: \\
:\end{array}$ & 88.83 & $\begin{array}{l}: \\
:\end{array}$ & 2,600 \\
\hline & : & & : & 2000 & $:$ & & $:$ & & $:$ & \\
\hline & : & & : & & : & & : & & : & \\
\hline & : & & : & & : & & $:$ & & $:$ & \\
\hline \multirow[t]{4}{*}{3} & : & & : & 2.70 & $:$ & 8.24 & $:$ & 89.06 & : & 40,000 \\
\hline & : & & : & & $:$ & & : & & $:$ & \\
\hline & : & & : & & $:$ & & : & & : & \\
\hline & : & & : & & $:$ & & $:$ & & $:$ & \\
\hline \multirow[t]{3}{*}{4} & $:$ & & : & 4.65 & $:$ & 8.70 & $:$ & 86.65 & $:$ & 100 \\
\hline & : & & : & & $:$ & & $:$ & & : & \\
\hline & : & & : & & $:$ & & : & & $:$ & \\
\hline \multirow[t]{4}{*}{5} & : & & : & 4.40 & $\vdots$ & 8.85 & : & 86.75 & $:$ & 550 \\
\hline & : & & : & & $:$ & & : & & : & \\
\hline & $:$ & & : & & $:$ & & : & & : & \\
\hline & $:$ & & : & 335 & $:$ & 8,34 & $:$ & 88,31 & $:$ & 2,200 \\
\hline \multirow{3}{*}{6} & : & & : & 0.00 & $:$ & 0.04 & $:$ & 00.01 & : & $2,<00$ \\
\hline & : & & $:$ & & $:$ & & $:$ & & : & \\
\hline & : & & $:$ & & $:$ & & $:$ & & : & \\
\hline \multirow[t]{3}{*}{7} & : & & : & 3.70 & : & 7.92 & : & 88.38 & : & 1,350 \\
\hline & : & & : & & : & & : & & : & \\
\hline & : & & : & & : & & : & & : & \\
\hline \multirow[t]{4}{*}{8} & $:$ & & : & & $:$ & & $:$ & & $:$ & \\
\hline & : & & : & 5.05 & $:$ & 8.89 & $:$ & 86.06 & $:$ & 120 \\
\hline & $:$ & & : & & $:$ & & $:$ & & $:$ & \\
\hline & $:$ & & $:$ & & $\vdots$ & & : & & $\begin{array}{l}: \\
:\end{array}$ & \\
\hline \multirow[t]{3}{*}{9} & : & & : & 5.65 & : & 8.56 & $:$ & 85.99 & : & 40 \\
\hline & : & & : & & : & & : & & : & \\
\hline & : & & : & & $:$ & & : & & : & \\
\hline
\end{tabular}


Table III. (Continued)

Analyses for August.

\begin{tabular}{|c|c|c|c|c|c|c|c|c|c|c|}
\hline \multirow{2}{*}{$\frac{\text { Dairy }}{\text { Number }}$} & \multicolumn{2}{|c|}{ Temp. } & \multicolumn{2}{|c|}{ Fat } & \multicolumn{3}{|c|}{$\begin{array}{l}\text { Solids : } \\
\vdots \text { not fat: }\end{array}$} & \multicolumn{2}{|c|}{ Water } & $\begin{array}{l}\text { Number of } \\
\text { Bacterla }\end{array}$ \\
\hline & : & Degrees & & ercer & $t: P$ & Percer & it:P & er cent & & Thousands \\
\hline 11 & $\vdots$ & & $:$ & 2.60 & $\vdots$ & 9.20 & $\vdots$ & 88.20 & $\vdots$ & 310 \\
\hline & : & & : & & : & & : & & : & \\
\hline & : & & $:$ & & $\vdots$ & & $\vdots$ & & • & \\
\hline 12 & : & & : & 3.10 & : & 8.80 & $\vdots$ & 88.10 & : & 565 \\
\hline & : & & : & & : & & : & & : & \\
\hline & : & & : & & : & & : & & : & \\
\hline & : & & : & & :: & & : & & & \\
\hline 13 & : & & : & 2.75 & : & 8.35 & : & 88.90 & : & 175 \\
\hline & $\cdot$ & & : & & : & & : & & : & \\
\hline & : & & : & & $\vdots$ & & $\vdots$ & & $\vdots$ & \\
\hline 14 & : & & : & 3.35 & : & 8.69 & : & 87.96 & : & 500 \\
\hline & 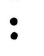 & & - & & : & & : & & : & \\
\hline & : & & : & & : & & : & & : & \\
\hline & : & & : & & $:$ & & : & & $\vdots$ & \\
\hline
\end{tabular}


Table IV.

Analyses for October.

\begin{tabular}{|c|c|c|c|c|c|c|c|c|c|c|}
\hline Dairy & : & Temp. & 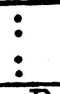 & Fat & $:$ & $\begin{array}{l}\text { Solids } \\
\text { not fa }\end{array}$ & $:$ & Water & 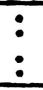 & $\begin{array}{l}\text { Number of } \\
\text { Bacteria }\end{array}$ \\
\hline Number & : & Degrees & $: P$ & er cen & $: P$ & er cen & $E: P$ & er cent & $:$ & Thousands \\
\hline & : & F. & $:$ & 80 & : & & $:$ & & : & \\
\hline 1 & ; & & $:$ & 3.60 & $:$ & 8.43 & $:$ & 88.97 & $:$ & 110 \\
\hline & : & & $\vdots$ & 4.00 & $\vdots$ & 9.39 & $\vdots$ & 86.61 & $\vdots$ & 120 \\
\hline & : & & : & & : & & : & & : & \\
\hline & $:$ & & $:$ & & : & & $:$ & & : & \\
\hline Average & : & & : & 3.80 & $:$ & 8.95 & : & 88.78 & : & 115 \\
\hline & : & & $:$ & & $:$ & & $:$ & & $:$ & \\
\hline & : & & : & & : & & : & & : & \\
\hline & : & & $:$ & & $:$ & & : & & : & \\
\hline 3 & : & & : & 4.20 & : & 8.00 & : & 87.80 & : & 820 \\
\hline & : & & $:$ & & $:$ & & $:$ & & $:$ & \\
\hline & : & & $:$ & & $:$ & & $:$ & & $:$ & \\
\hline & $:$ & & $:$ & & $:$ & & $:$ & & $:$ & \\
\hline 4 & : & & : & 3.70 & $:$ & 7.90 & : & 88.40 & $:$ & 50 \\
\hline & : & & $:$ & & $:$ & & $:$ & & : & \\
\hline & : & & $:$ & & $:$ & & $:$ & & $:$ & \\
\hline & : & & $:$ & & $:$ & & $:$ & & $:$ & \\
\hline 8 & : & & $:$ & 4.40 & $:$ & 8.87 & $:$ & 86.73 & $:$ & 70 \\
\hline & : & & : & & $:$ & & $:$ & & $:$ & \\
\hline & : & & $:$ & & $:$ & & $:$ & & $:$ & \\
\hline & : & & $:$ & & $:$ & & : & & : & \\
\hline 12 & : & & : & 3.70 & : & 8.90 & : & 87.40 & : & 675 \\
\hline & : & & $:$ & & $:$ & & $:$ & & $:$ & \\
\hline & : & & : & & $:$ & & $:$ & & : & \\
\hline & : & & : & & : & & $:$ & & $:$ & \\
\hline
\end{tabular}




\section{Table V.}

\section{Analyses for January.}

\begin{tabular}{|c|c|c|c|c|c|c|c|c|c|c|}
\hline Dairy & $\begin{array}{l}: \\
:\end{array}$ & Temp. & $:$ & Fat & $:$ & $\begin{array}{l}\text { Solids } \\
\text { not f8 }\end{array}$ & 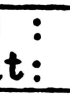 & Water & : & $\begin{array}{l}\text { Number of } \\
\text { Bacteria }\end{array}$ \\
\hline Number & : & Degrees & $:$ & Percen & $t: P$ & er cen & $t: P$ & er cent & $t:$ & Thousands \\
\hline & : & F. & $:$ & & $:$ & & : & & : & \\
\hline \multirow[t]{6}{*}{1} & : & & $:$ & 3.65 & : & 8.71 & : & 87.64 & : & \\
\hline & $:$ & & $:$ & & $:$ & & $:$ & & : & \\
\hline & $:$ & & : & 3.60 & : & 8.31 & $:$ & 88.09 & $:$ & 167 \\
\hline & : & & $:$ & & $:$ & & $:$ & & $:$ & \\
\hline & : & & $:$ & & $:$ & & $:$ & & $:$ & \\
\hline & $:$ & & $:$ & & $:$ & & : & & $:$ & \\
\hline \multirow[t]{4}{*}{2} & : & 54.0 & $:$ & $---\infty$ & $:$ & $-\infty-$ & $:$ & --- & $:$ & 600 \\
\hline & : & & : & & : & & $:$ & & : & \\
\hline & : & & : & & $:$ & & : & & : & \\
\hline & : & & : & & $:$ & & $:$ & & $:$ & \\
\hline \multirow[t]{4}{*}{4} & : & 52.0 & : & 4.30 & $:$ & 8.22 & $:$ & 87.48 & $:$ & 88 \\
\hline & : & & $:$ & & : & & : & & : & \\
\hline & : & & $:$ & & $:$ & & $:$ & & : & \\
\hline & : & & : & & $:$ & & $:$ & & $:$ & \\
\hline \multirow[t]{4}{*}{5} & : & 58.0 & $:$ & 3.40 & $:$ & 8.46 & $:$ & 88.14 & $:$ & 112 \\
\hline & : & & $:$ & & $:$ & & $:$ & & $:$ & \\
\hline & : & & : & & : & & $:$ & & $:$ & \\
\hline & $:$ & & $:$ & & $:$ & & $:$ & & : & \\
\hline \multirow[t]{4}{*}{6} & : & 62.0 & : & 4.00 & $:$ & 8.18 & $:$ & 87.82 & : & 97 \\
\hline & : & & : & & $:$ & & $:$ & & : & \\
\hline & $:$ & & $:$ & & $:$ & & $:$ & & : & \\
\hline & : & & : & & $:$ & & $:$ & & $:$ & \\
\hline \multirow[t]{4}{*}{8} & : & 68.0 & : & 3.60 & $:$ & 8.38 & $:$ & 88.02 & : & 360 \\
\hline & $:$ & & : & & $:$ & & $:$ & & : & \\
\hline & : & & $:$ & & : & & $:$ & & : & \\
\hline & : & & : & & $:$ & & $:$ & & : & \\
\hline \multirow[t]{4}{*}{13} & : & & $:$ & 2.60 & : & 8.53 & : & 88.87 & : & 7 \\
\hline & : & & : & & : & & : & & : & \\
\hline & : & & : & & $:$ & & $:$ & & : & \\
\hline & : & & : & & $:$ & & $:$ & & : & \\
\hline
\end{tabular}


Following is a summary of the conditions found during the first three months. (This summary in part had to be compiled at that time because of a request on the part of the St. Charles city council for a report of the condition of their milk supply.)

\section{Table VI.}

Summary of Analyses for June, July and August.

\begin{tabular}{|c|c|c|c|c|c|c|c|c|c|c|c|}
\hline No.: & Amt. & $\vdots$ & Temp. & $\begin{array}{l}\text { Number } \\
\text { :Bacteris }\end{array}$ & f: & Fat & & $\begin{array}{l}\text { Sol1ds } \\
\text { not } \mathrm{fg}\end{array}$ & $t:$ & Water & : score \\
\hline & Gal. & & & Thousand & $\overline{s: \bar{F}}$ & er cer & & Per cer & $t: F$ & er cen & $t:$ \\
\hline 1 & 45 & $:$ & $\begin{array}{l}\text { F. } \\
72.0\end{array}$ & 619 & $:$ & 3.30 & & 8.53 & $\vdots$ & 88.53 & $\vdots 67.25$ \\
\hline 2 & $: 10$ & $:$ & 62.3 & 3,205 & $:$ & 3.76 & s & 7.60 & $\begin{array}{l}\vdots \\
:\end{array}$ & 88.15 & $\begin{array}{l}: \\
: 36.75\end{array}$ \\
\hline 3 & 25 & $:$ & 78.0 & $: 47,083$ & $\vdots$ & 3.99 & & 8.13 & $\vdots$ & 87.87 & $: 34.00$ \\
\hline 4 & 13 & : & 73.0 & 1,208 & $\vdots$ & 3.41 & & 8.32 & $\vdots$ & 87.84 & $: 35.00$ \\
\hline 5 & 22 & $:$ & 71.5 & 2,952 & $\vdots$ & 2.83 & 2 & 8.88 & 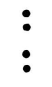 & 87.92 & $: 31.00$ \\
\hline 6 & 15 & : & 64.5 & 2,585 & $\vdots$ & 3.35 & 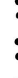 & 8.36 & $\vdots$ & 88.24 & $\vdots 53.25$ \\
\hline 7 & $: 15$ & : & 67.0 & 7,183 & : & 3.70 & : & 7.96 & $\vdots$ & 88.34 & $: 45.75$ \\
\hline 8 & 10 & : & 78.5 & $\vdots 11,145$ & $\vdots$ & 5.38 & : & 8.41 & $\vdots$ & 85.73 & :32.00 \\
\hline 9 & 10 & $:$ & 77.0 & 845 & $\vdots$ & 4.00 & : & 8.77 & $\vdots$ & 87.05 & $: 44.25$ \\
\hline 10 & 10 & : & $\cdots$ & 40 & $\vdots$ & 3.70 & : & 8.75 & $\vdots$ & 88.55 & $: 36.75$ \\
\hline 11 & 8 & : & 75.0 & 187 & $\vdots$ & 2.93 & : & 9.03 & $\vdots$ & 88.03 & $: 37.50$ \\
\hline 12 & 4 & : & 68.0 & 533 & $\vdots$ & 3.00 & : & 8.78 & $\vdots$ & 88.13 & 37.25 \\
\hline 13 & $: 15$ & . & $-\cdots$ & 175 & $\vdots$ & 2.70 & & 8.35 & $:$ & 88.92 & \\
\hline 14 & 15 & • & $\ldots$ & 500 & $\begin{array}{l}\vdots \\
\vdots \\
\vdots\end{array}$ & 3.35 & : & 8.69 & $\vdots$ & 87.96 & $\begin{array}{l}\vdots \\
\vdots \\
\vdots\end{array}$ \\
\hline
\end{tabular}




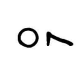

ov ob
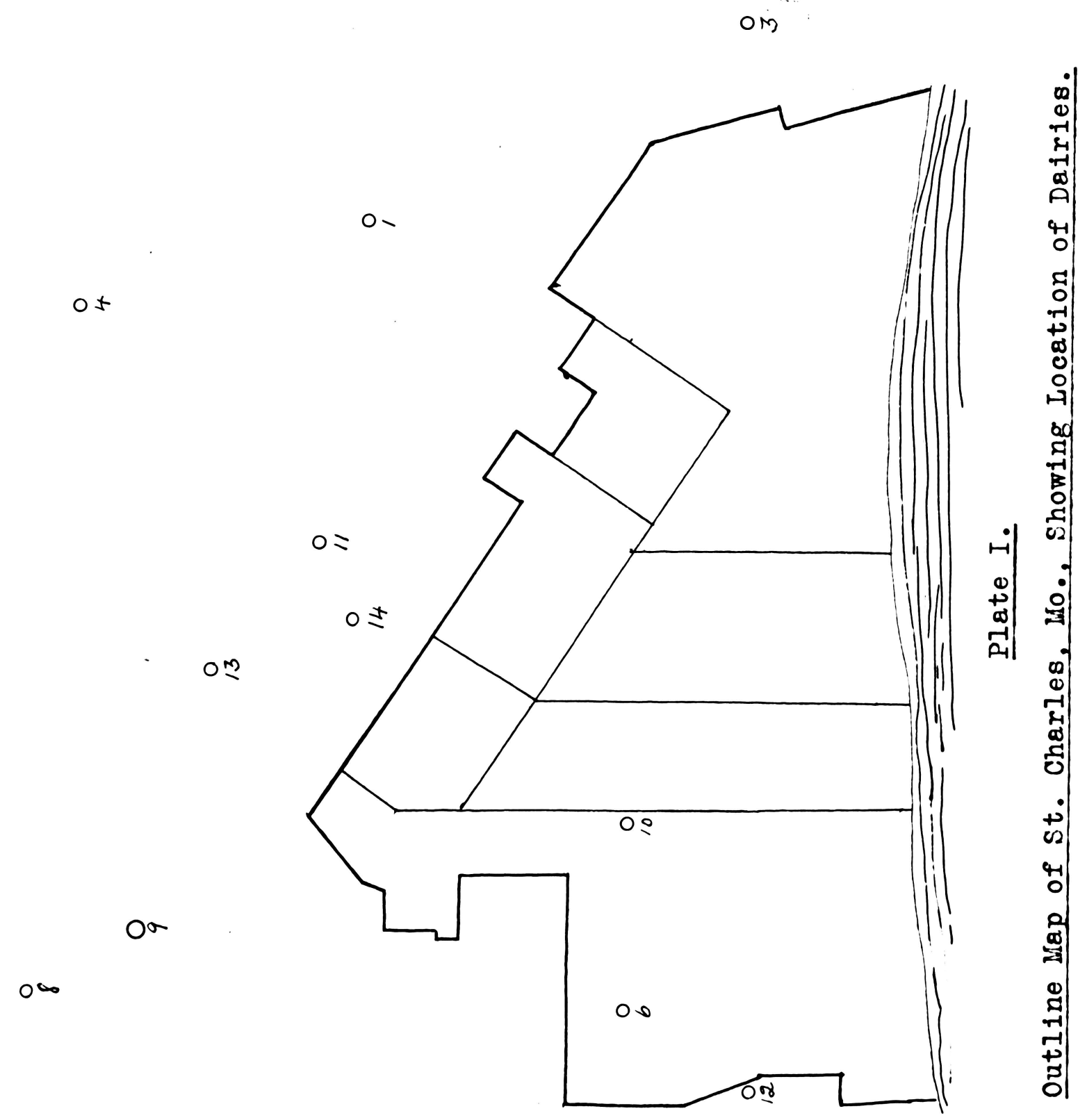


\section{Preliminary Survey.}

The conditions surrounding the production and distribution of the milk were studied at the farms and on the streets. Visits were made to each of the dalrymen supplying milk to the town. Reference to the accompanying map will show that the dalrymen were distributed on all sides of the town. Their datry barns and equipment were scored by the use of the United States Department of Agriculture, Bureau of Animal Industry Score Card; the destred data regarding their business were obtained by questions and observations; and the nature of the plan to investigate the milk supply and to assist the dalrymen was explained to each as follows: "The agricultural college is an instituticn mairtained for the purpose of serving the farmers of the state. We believe we can serve you in a way which you may not have suspected. The consumers of this town are becoming interested in the question of fure milk. Other towns in the state have done much to improve and control their milk supplies and the people of this town are getting ready to dc the same. The Women's Civic club, as you know, recently had the state reterirarien here to talk to them on the subject of tuberculosis and the milk supply. The college has 
noted this activity on their part. We know that a true solution of the problem can be reached crly if the true nature of the problem is determined. We have seen cities go thru tedicus and disagreeable experiences in attempting to regulate their milk supply by passing ordinances borrowed from other towns which do not suit their conditions. It is our purpose to make an investigation of your supply and to be ready to represent your interests in any future attempt on the part of the town to regulate the sale of your product. In order to do that, we must know first just what is the condition of the milk supply of this town. Perheps the supply is not in need of improvement. We also wish to learn from each dairyman his sugesticns as to what public means of cortrol he thinks should be taken. From talking to the cther dalrymen, I am lead to believe that you are not growirg rich at your trade. There are certain factors, such as low price for your product, high cost of feed, ond competition of farmers who bring milk in irregularly at cut prices, which may affect your income. It is perheps causes of this sort which prevent you from usirg better methods. If so, the consumers should be so informed; sc that no injustice will be forced upon you. 
We want to visit your farms at different times during the year to see what methods you are using in handling your milk. We want to collect samples of milk from your wagons and test them, as they do in other cities, for the per cent of fat and water, and number of bacterie; so that you may know just how your milk compares with milk of towns whose supply is under careful supervision."

Thrucut this discourse interruptions were frequently made with remarks to this effect: "Those women will be the ruin of this country"; "My customers are well satisfied with my milk, I see no reason for any improvement." "No, we're not making any more than encugh to pay for our feed this year. If they kick, we'll go out of the busiress." "Sure, you can inspect my dalry any time you want. You won't find me watering my milk." "What are you coing to do with that milk you collect?" etc.

On the whole, a reasonable measure of cocperation was secured from all of them. Many were skeptical as to the good that was to come from 1 t. Some doubted the earnestness of the consumers' effort to carry thru a measure of reform. But none could see where it would do them harm to cooperate, and did see that if they stood in the way, they might suffer. 


\section{Conditions as Found on the Farms.}

There were certain conditions found existing on all the farms. None of the dairymen used the modern small top pail during milking; none made use of ice in cooling the milk. Cooling of nights milk in well water was practiced by nearly all; while the mornings milk was delivered warm as a rule. Only one dalryman deIivered all bottled milk (4 gallons); six bottled a small per cent. All but one delivered the major portion of their milk by dipping from elght galion cans. Only one dairy was equipped with a modern barn with the recommended amount of air, light, proper ventilation, etc. Tho in general the cattle appeared healthy from an external examination, only one herd was tuberculin tested. This herd was the cnly pure bred herd in the community. Because cf the activity of their owners durirg the succeeding pericd, the following selected list of dairies are of particular interest.

\section{Description ef Dairies:-}

No. 1 , owned and operated by Mr. H. F. F. A farm of 40 acres of rolling land, one-half mile from town, valued at approximately $\$ 250$ per acre; 17 acres in pasture and 24 under the plow. Equipped with 
residence, horse barn, cow barn, two silos, milk house adjoining barn, chicken house. He milks twenty cows. Cow barn is thoroughly modern, equipped with stanchions, concrete floor, gutters, mangers and alleys; King's ventilation system; plenty of light, good milk room equipped with cooling tank, surface cooler, scales and milk sheet; well dralned barn yard. Dairy scored 67.75 , with 26 points on equipment and 41.25 on methods.

Mr. F. is of thrifty German extraction. He has been in the business seven years and finds it profitable. He hopes to improve and to keep up his excellent reputation in town for clean milk. He showed a fire spirit of cooperation in any attempt to better the conditicns. He had no fear that he could not keep up to the requirements.

He peddles 45 gallons of loose milk from two wagens, which cover on the average 10.8 miles of c1ty streets, delivering at the rate of 16.36 quarts of milk per mile. Mr. F. Is easily the best, most substantial dalryman of the community. 
No. 2, a farm of 52 acres of rolling land, owned and operated by Mr. A. S. Equipped with residence, chicken house and machine shed, cow and horse barn, and milk house. Milks nine cows; delivers 10 gallons of dipped milk and 3 of bottled milk from cre wagon. The barn is without floors; cows tied by ropes to mangers; lacking in light and in filthy condition. Water supply pumped from surface stream and carrled from a spring, which is open to surface contamination. The milk house is of good construction, but is inexcusably filthy. Cooling tank was filled with foul water. The plant scored 36.75, with 17.50 for equipment and 19.25 points for methods.

Mr. S., German, is a hardworking but careless dairyman. He experiences a good deal of trouble with souring of his milk and disbelieves in bacteria as a cause. He peddles 10 gallons of milk over 3.26 miles, or at the rate of 12.26 quarts per mile.

No. 3, a farm of 40 acres of Missour1 bottom land, one-fourth of a mile from town, rented and operated by Mr. F. W. It is equipped with residence, horse and cattle barn; milk house and chlcken shed.

He milks twenty cows, which are kept tied to the wall in an old barn with no windows, low celling, 
and rough walls, dirt floor. There are doors behind every twc cows. The milk house and well are in the barn yard, which is wet and mucky on three sldes of the house. There is a swamp close by, thru which the cattle wade in coming from the pasture. The dairy scored 34, with 13.75 for equipment and 20.25 for methods. Mr. W., German, is a most unprogressive, ignorant man; father of twenty-five children, thirteen living, who, sick and filthy, milk the cows and care for the milk. Two little ones showed bad cases of the pink eye and one a ringworm.

Two of the children peddle 25 gallons of his milk a day from one wagon, which covers 7.65 miles of streets, delivering 13.6 quarts per mile. This dairy is considered to be one of the worst, not only because of the poor dairy equipment and dirty conditions at the barn, but because of the fgnorance of the owner and the filthiness of the persons handing the milk. The possibilities of contaminating the milk with human diseases are extreme.

No. 6, a 36 acre dairy farm, bordering the c1ty limits, rented and operated by Mr. N. A. B., a native of Switzerland. He is a breeder of pure bred Holstein cattle, and Buff Orpington chlckens. He has 
20 acres in pasture and 13 under the plow. Farm equipped with small residence, horse shed, cattle barn, milk house, wagon shed and chicken house. He milks ten cows valued at $\$ 2500$, and uses a pure bred bull valued at $\$ 250$. The dairy scores 53.25, with 22 on equipment side and 31.25 on method. He is the only dalryman whose herd is tuberculin tested.

The barn is equipped with wooden stanchions, wooden floor, gutters and mangers; sliding windows, low celling. He weighs his milk and removes it from the barn when a can is full. Cools it over a surface cooler. He peddles about 15 gallons of milk from one wagon, 3 gallons of which is bottled. He is clean, thrifty, ambitious, well read, and anxious to improve. He peddles 13.37 quarts per mile of streets covered, or 15 gallons over 4.48 miles.

No. 10, a small dalry located on a $50 \times 200$ ft. city lot, with a 5 acre rented pasture. Operated by Mrs. S. Equipped with residence, cow barn and chicken house. She milks 6 cows, and by the ald of four to six children delivers twice a day 10 gallons of milk put up in individual tin buckets.

The barn has a dirt floor, no stanchions; cows tied two in a stall to mangers; open celling 
covered with straw; poor light, cattle crowded for room. Floors were dirty. The barn yard has a good slope, but has a street sewer emptying into it thru whlch the cows walk. Milking is done by Mrs. S., who 1s personally clean and careful. Dalry scored 36.75 , with 9.75 for equipment and 27 for methods.

Nrs. S. Is industrious and fearful of changes. She may go out of business any time. She feels she is delivering the best $\mathrm{mllk}$ in town and is conscientious about it. Wliling to have milk tested and place scored.

Resume' of Conditions.

Examination of the data given above shews the condition of the milk supply of St. Charles to be very poor. Approximately fifty per cent of the total contains over a million bacterla per cublc centimeter, putting it in a third grade class. Twenty per cent of the milk supply of the clty, according to the tests made, contained less than three per cent butter fat, and the extreme range of fat percentage in all samples tested was betreen $1.6 \%$ and $7.5 \%$ Observations at the farms indicate the extreme liability of infection of the milk by disease if present on the farm, in the 
home, or in the cattle. The use of cows not known to be free from tuberculosis, and the handling of milk and utensils in the home, where human disease exists, cannot fail to render the milk of such dairies dangerous; unless pasteurized.

On the whole, the milk is unsafe, (1) because of the number of bacteria it contains and the extreme liklihocd of infection by disease germs, and (2) because of the uneven per cent of fat. It is not only frequently below the state standard; but, because of its variability, may seriously interfere with the feeding of chllaren when milk of normal composition is required. 


\section{C.AUSES.}

The results of the investigation as outlined in the foregoing section reveal a condition which was undoubtedly in need of improvement. As before stated, in attempting to improve the situation, it was belleved that the causes for the conditions as they existed had to be determined.

\section{Immediate Causes.}

High Bacterial Count:-

Judging from the filthy conditions surroundIng the production of the milk at the farms, it is subjected to a heavy original contaminaticn of dirt and bacteria. The high temperatures at which the milk is held during storage and delivery is undoubtedly responsible for a very rapid multiplicaticn of the bacteria.

In the case of Dalry No. 2, where the bacterial count was high, even though the temperature was low, the agar plates showed a large per cent of putrefactive organisms. Fixamination of the premises revealed the use of a cooling tank in which the water was festconed with foul smelling slime. Water for vashing 
the utensils came from a surface spring and pasture stream.

Variation in the Per Cent of Fat:-

The wide variation in the per cent of fat in different samples of milk from the same dalries was explained by the cccasional skimming of nights milk to supply a varying cream trade, and by the method of delivery. The milk is delivered by dipping and pouring from cans. Unless care is taken to thoroly mix the milk, dipping from the can will result in wide variation in the per cent of fat in different portions. There is, of course, a material variation in the per cent of fat from the different herds, some belng Jerseys and others Holsteins.

\section{Danger from Disease:-}

The use of cattle not known to be free from tuberculosis; the presence of disease on certain farms and homes where milk is handled and utensils cleaned; and the entrance of dirt in considerable quantities to the milk, constitutes the justification for tho belief that some of the milk supplied St. Charles is unsafe as an article of food. 
Underlying Causes of the Use of Faulty Methods.

The underlying causes for the low grade of St. Charles milk are to be found (1) in the personal characteristics of the dalrymen themselves--education, attitude, moral responsibility; (2) in the eccnomic status of their business; (3) the relaticnshtp between the communtty and the milk problem.

\section{Personal Causes:-}

In general, the education of the dafrymen in the essentials of sanitary milk producticn and distributicn is faulty, the in most cases the ability to learn exists. Any feeling of responsibility for the health of their customers is entirely lacking, except in two or three frstarces.

In a few cases the man in charge was entirely unsuited to the business of producing infant food, e.s evidenced by low ldeals, dishonesty, irresponsibility, and dirt. No matter what the demand for good milk may be, unless these personal characteristics can be corrected, clean milk cannot be obtained. 


\section{Economic Causes:-}

Low profitg have considerable influence upon the methods used by the dairymen. The low income is due more to expensive production and poor management than tc a low price for the product. Seven cents a quart for "loose milk" is not low, when bottled milk sells for only elght and nine cents in neighboring communities. Low producing cows, poor feeding, and expensive delivery of milk are the causes of low managerial incomes.

A summary of data collected on the milk routes shows that of 38.76 miles of streets in st. Charles, only $24.25 \mathrm{miles}$ are used by the dairymen. But, during one day's delivery, fourteen dairymen travel $74.5 \mathrm{miles}$ over these $24.25 \mathrm{mlles}$ of streets. In other words, the streets are covered on an arerage of three times. Some streets are covered as high as nine times; while seven miles, or approximately onethird of the streets used, were traversed four times by different milk wagons each day.

It requires sixty-four man and horse hours to deliver 222 gallons of milk over $74.5 \mathrm{mlles}$ of streets, at an average rate of 2.97 gallons per mile. It is estimated thet if distributed from a centrally located plant, it would require only twenty man and 
horse hours to deliver the same amount of milk; or the time of four men and horses 5 hours per day. The wagons need travel over a little less than 24 miles. This Indicates a dally waste of 44 horse and man hours, which, if valued at $30 \mathrm{cts}$, an hour, would equal a total of $\$ 13.20$. 
Table VII.

Data Fegarding Route Investigation.

\begin{tabular}{|c|c|c|c|c|c|c|c|c|}
\hline Dairy & 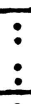 & $\begin{array}{l}\text { Route } \\
\text { Length }\end{array}$ & $\vdots$ & $\begin{array}{c}\text { Milk } \\
\text { Delivered }\end{array}$ & $\vdots$ & $\begin{array}{c}\text { Rate per } \\
\text { Mile }\end{array}$ & $:$ & Time \\
\hline Number & 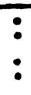 & Miles & 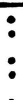 & Gallons & : & & 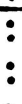 & Hours \\
\hline 1 & $\vdots$ & 10.80 & : & 45 & $\vdots$ & 4.17 & $\vdots$ & 9.0 \\
\hline 2 & $:$ & 3.26 & 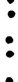 & 10 & $:$ & 3.07 & : & 3.0 \\
\hline 3 & $:$ & 7.65 & : & 25 & $:$ & 3.27 & $\vdots$ & 6.0 \\
\hline 4 & : & 7.10 & $:$ & 20 & $\vdots$ & 2.82 & : & 5.0 \\
\hline 5 & : & 9.07 & $\vdots$ & 25 & $:$ & 2.76 & : & 5.0 \\
\hline 6 & $\vdots$ & 4.48 & : & 15 & $\vdots$ & 3.35 & : & 4.0 \\
\hline 7 & : & 4.02 & : & 15 & $:$ & 3.73 & $:$ & 4.0 \\
\hline 8 & $\vdots$ & 3.55 & : & 10 & : & 2.82 & $:$ & 6.0 \\
\hline 9 & : & 3.20 & : & 10 & : & 3.12 & : & 3.0 \\
\hline 10 & : & --- & : & - & : & $\cdots$ & : & -- \\
\hline 11 & : & 4.31 & : & 8 & $:$ & 1.85 & : & 3.0 \\
\hline 12 & : & 2.33 & : & 4 & : & 1.71 & : & 1.5 \\
\hline 13 & : & 7.86 & : & 20 & : & 2.55 & : & 7.0 \\
\hline 14 & : & 3.55 & : & 15 & : & 4.23 & : & 4.0 \\
\hline 15 & : & 3.32 & : & 10 & : & 3.01 & 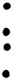 & 2.5 \\
\hline Total & $\vdots$ & 74.50 & : & 222 & : & & : & 64.0 \\
\hline Average & $\vdots$ & 4.97 & : & 14.79 & $\vdots$ & 2.97 & 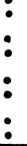 & 4.27 \\
\hline
\end{tabular}


The economic loss in a year from this source slone vould build and equip a $\$ 4800 \mathrm{milk}$ distributing plant.

The chief expense in this sort of a delivery, however, and the chief loss to the dalrymen, is in the potential value of their time. Examination of the farms shows that, as the work is at present organized, these men are makirg more by their time on the wagons than they would at home. If, however, they would spend more time in breeding and feeding better stcck, keeping records, caring for more acres, and ralsing better crops, and giving more attention to advertising and study, they could realize far more from their time than by spending from a fourth to a third of thetr time doing the work of a $\$ 30$ man on a delivery wagon. Dalryman No. 14 hires a $\$ 30$ man to deliver his milk, to do milkirg and farm work besides, and uses the time thus saved in managing a cattle trading business. By a proper study of their resources and capabilities, the other dairymen could likewise increase their incomes. 


\section{Social Causes:-}

The true baslc calise of a poor milk supply is to be found in the community receiving the milk. An insistent and intelligent demand for wholescme milk is necessary in the long run for its obtainment. Because of the lack of such a demand, the wrong type of dalryman has been attracted into the field of market milk production, and those of the proper type have falled to learn or to use the proper methods. Before the dairymen will deliver a high grade of milk; yes, before they will accept an education in the proper methods of its production, the demand for such milk must be created in the comuntty. The lack of such a demand has been termed the "socleil cause" for a low Erade milk supply. 
V. FFFORTS FOR INPROV FIIFNT -- RESULTS OBTAINED.

\section{Introduction -- Agencies at Hand.}

The problem of securing a better milk supply is a community problein. The dalrymen follow their trade for the money there is in it, supplying the qual1ty of milk which is demanded, insisted upon, and paid for by the consumer. The consumer desires a good grade of food at the lowest possible price. The ccmmunity as an organization is interested in pure milk only to the extent that it affects community interests and the public treasury. A bad situation exists in St. Charles because the consumer, the dafrymen, and the community do not appreciate or understand their relation to the problem and the relative importance of the factors under their control. The problem of reforming such conditions is one malnly of educating those directIy interested; nanely, the dairymen, the consumer, and those in charge of directing the community interests, including the roters.

The agencies employed in carrying out the educational program which was followed were the press, consisting of twc local newspapers; the St. Charles Chamber of Commerce, and the Women's Civic Club, 
organizations whose purposes are to further the business, social, and general interests of the town; the city council and Board of Health; the county farm advisor, and the dairymen themselves.

The press, particularly the st. Charles Banner News, was by far the greatest single factor in awakening a public sentiment in favor of clean milk. The Chamber of Commerce and the Women's Civic CIub gave the movement their moral support and endorsement, which helped greatly in impressing the importance of the matter upon the producers and consumers alike. The dairymen themselves, by their sincerity and pride, have aided in effecting a change in the quality of the m11k supply.

\section{Efforts for Improvement.}

The efforts for the improvement of the situation were directed at removing, as far as possible, the underlying causes for the existence of the unsafe milk supply; those personal causes, consisting of $1 \mathrm{~g}$ norance of dairymen in matters of sanitary milk product1on, presence of dalrymen unsulted to the business who show no promise of improvement, existence of a destructive jealousy and competition; those economic causes, 
consisting of expensive production and distribution of nilk and lack of differentiation in price between good and bad milk; and those soclal causes, consisting of lack of insistent demand for high grade milk and its control by the city or state.

Remcval of Personal Causes:-

Ignorance of Dairymen: Personal interviews with the various dairymen while scoring and inspecting their farms, and on the streets while collecting samples, and at all meetings of the dalrymen, afforded excellent opportunities to educate the men in the principles of clean milk production and distribution, and to their responstbility for the health of the children they served. As a result of these interviews, every dalryman became acqualnted with the important sources of bacteria in milk and the metiods of preventing bacterial contamination; the relation of temperature to the bacterfal growth and efficient methods of cooling; the liability of infection of milk with disease germs and the modes of safeguarding it.

Unfit Da1rymen: Dairymen Nos. 3, 10, and 14 were considered unfit for the business of handling as dellcate and important a food as milk. No. 3 and No. 14 showed 
such an entire lack of ideals in the handling of their milk that education and help in its economlc production would have IIttle effect on the quality of their product. No. 10 was producing a fair grade of milk, but It was badly exposed to disease contamination. The dalry barn itself was located in the same yard with the outlet of a street sewer, and the woman operating the dairy, tho thoroly consclentious, was hopelessly ignorant about disease and its spread. She was weak minded and surrounded by dirt, bad air, and unkept children. The milk was all handled at the house, where it could be easily contaminated by disease if it should break out in the family.

No. 14 was in a cattle trading business, and ran his dairy as a side line, with no intention or desire for improvement. The husband of the woman operatIng dalry No. 10 was a factory worker; so that nelther of these would be deprived of means of support if their dairies were eliminated. These dalries were discredited in a private way anong the other dalrymen, business man, and consumers who showed interest in the milk situation; tho no public comment was made.

By October, the trade of dalryman No. 3 had so diminished that he started shipping all his milk to st. Louis, and finally, before the first of the year, he sold out entirely to F. Brothers, who took over his 
route. During December, No. 10 sold out to No. 1, the most progressive and best dairyman of the town. No. 10 was most conscientious about her milk business, and keenly felt the adverse criticism. She sold out for personal reascns, it was reported.

$$
\text { Durirg November, dairyman No. } 9 \text { stopped }
$$

delivery. He was a good dairyman, but preferred stopping his delivery to taking any special pains with his milk.

The elimination of Dalries No. 3 and No. 10 was a distinct advantage to the City of St. Charles. Twenty-five gallons, or ten per cent of the total milk supply, when delivered by No. 3, was the worst milk in town. Twenty gallons of this is now produced and deinvered by the E. Brothers, two energetic, promising ycung dairymen. The other five gallons, plus the ten gallons from No. 10, are now belng produced and delivered by No. 1. The ten gallons of No. 9 unfortunately fell into the hands of No. 2, whose milk was of a low sanitary quality.

Destructive Competition and Jealousy: While competition has its good features, It can become destructive if it prevents cooperation in matters of mutual interest. Such a competition existed between the dalrymen of St. Charles, and was concelved to be one factor 
in the way of a better milk supply. To remove this factor, matters of mutual interest were pointed out to them, such as collective buying of feed, community breeding, central distributing plant, price guarantee for milk, collective advertising, organized effort to protect their interests in any reform movement by the consumers.

They first showed a general interest in the idea of a central distributing plant. Two meetings were held at which the leading dalrymen heard the possibilities of such a plant and the results of the route investigation, which revealed the possible saving of time and expense in delivery of milk. The advisability of charging a higher rate for bottled milk was also considered. The meetings resulted in resolutions to investigate the cost of starting a cooperative distributing milk plant and the possiblilties of its dereloping dalry manufacturing as a side line, and to get as many of the better dalrymen interested as possible. After the last meeting, which was held on Farm No. 1, the visiting dairymen inspected the barns, cattle and equipment of this highest scoring dairy.

The point of interest in this connection is the effect on the dalrymen of these meetings for discussion of problens of mutual interest. Tho no distributing 
plant was organized, a seed of cooperation was planted, which sprouted in November, in the formation of the St. Charles Dairymen's Association, organized for the purpose of advancing the dairy interests of that section.

Not the least important effect upon the dairymen of these meetings, both individual and collective, was the development of a pride in their business as producers of human food.

Removal of Economic Causes:-

The efforts to remove the economic causes of impure milk; namely, the lnability of the dairymen to use more expensive methods and equipment for production, due to low managerial incomes, have already been briefly described. The efforts aimed to bring about the use of better and healthier stock, better methods of feeding and breeding, development of a reputation for good milk, better use of their time, cooperation in the buying of feed, distribution of their product, advertising same, mutual agreement on price to be recelved for milk, etc.

No open meetings for the discussion of feeding and breeding problems were held, but whenerer interest could be aroused in these questions, they were discussed. It is one of the purposes of the Dalrymen's 
Association to hold meetings for this purpose. The suggestions to the effect that bottled milk should command a higher price was taken up by the dairymen and resulted in a differentiation in the price of bottled and "loose" milk. In November, after a meeting of the dairymen, the price of "loose" milk was raised from 28 to 33 cents per gallon, and the bottled milk from 28 to 40 cents.

Newspaper comment and editorials concerning the tuberculin testing of herd No. 6 , which appeared in the Banner News in December and January, have resulted in the testing of that and three other herds. In December, herds Nos. $1,6,7$, and the herd of a new dairyman were tested. The milk from these herds represents forty-one per cent of the total St. Charles milk supply. Two other dalrymen, No. 5 and No. 13, representing elghteen and one-half per cent of the supply, have agreed to test when the state Veterinarian can make the tests. The Dalrymen's Association has undertaken to have the remainder of the herds tested. This testing for tuberculosis, with subsequent elimination of tubercular cattle, is a direct benefit to the consumer. It is mentioned here, however, because it was brought about by pointing out the relationship between the use of tubercular free herds and increased dairy profits. 
The increased profit came from an increased demand for the product of these dairies. In this connection it should also be noted that the public has shown its interest and growing intelligence in the milk question by shifting its patronage to the better dairymen.

Removal of Social Causes:-

The lack of an insistent and intelligent demand for pure milk, together with an unwillingness to paj for the increased cost of cleanliness and safety, is concelved to be the chief cause of a faulty milk supply. The producers will eventually produce what is demanded. In a community as large as st. Charles, it is doubtful whether the demand of the individual consumers alone will ever result in the complete safeguarding of their milk. Before that can be done, the organized community, acting thru the Board of Health, will have to create a community standard or demand for pure, safe milk, and control 1t. The purposes of this portion of the reform were, therefore, in large measure to educate the consumer in the meaning and importance of clean milk and in a realization of the increased value of such milk; and to point cut to the community as a whole the manner of creating a community demand and control of their milk. 
Realizing at the outset that the community would have to take part in a reform, regardlegs of the causes which were to be found for the milk situation, representative bodfes of the consumers and business men of the town were interviewed regarding their attitude toward the investifation. Both the chamber of Commerce and the Women's Civic Club declared their interest in the movement, and desire to be of ald. At that time their endorsement and backing was all that was needed, as it gave assurance of their cooperation, and some excuse for putting the matter before the dairymen. On September 14th, an article reporting the activities of the city councll appeared in the press, from which I quote the following:

$$
\begin{aligned}
& \text { "On motion an effort will be made to } \\
& \text { get a representative of the University } \\
& \text { to meet with the ccuncil and take } \\
& \text { steps to have ordinance drafted } \\
& \text { providing for the inspection of milk, } \\
& \text { dairies, and cattle." }
\end{aligned}
$$

By October 15th no officlal notice had been recelved regarding this action, sc a letter was sent to the secretery of the Chamber of commerce, in which was set forth our desire to put before the people of St. Charles the truth regarding their milk situation. 
Considering the character of the mayor and the city council, and a slight jealousy that existed on their part for the work undertaken and accomplished by the Chamber of Commerce, the secretary decided that the mayor should be appealed to directly, that he and the council might have the credit of the initiative in the mevement. A visit to the mayor was made, with the result that he agreed to call a meeting of the council, Board of Health, agricultural committee of the Chamber of Commerce, press and farn advisor, for a consideration of our recommendations.

On october 27 th this meeting occurred. The meaning of the investigation, the condition and causes found, the recommendations for improvement were explained.

Action of some sort was asked for. Upon the suggestion of the Chamber of Commerce, the Board of Health assumed the responsibility of taking the lead in conducting a reform. A meeting of the Board of Health and those whom they thought could be of ald, such as the Chamber of Commerce and Women's C.1vic C.Iub, was arranged for the night of November 13th. The banner News printed a full report of the meeting. That it resulted in a widespread interest among the consumers of St. Charles milk was evidenced 
by a letter received on the 30 th from Dalryman No. 1, in which he said that many of the dairymen complained of criticism and poignant questicns by their consumers.

On November loth, the dairymen had a meeting, which resulted in the accompanying letter that was reported in the Banner News on the 11th:

"Editor of Banner News:

Referring to the article published in the Banner News scme time ago the dairymen have the following to say:

The average milk sold to the consumers of St. Charles is as good or better than the average milk that is bought by dairymen of st. Louis from the farmer. The st. Loufs dalrymen weuld be only toc glad tcbuy the St. Charles milk supply. After the milk reaches the dalry in St. Louls, it is pasteurlzed and bottled, then sold for 10 cents to 14 cents per quart.

Pasteurizaticn does not increase the food value of the milk. One of the chlef reascns why milk is pasteurlzed in St. Louis is that it will keep longer. The average time before the consumer gets the milk in St. Louls is 35 hours; while in St. Charles it is 10 hours. If people in St. Charles 
want $A$ and $B$ grade milk, we will be willing to furnish it at $A$ and $B$ grade prices. The bulk of milk sold in St. Charles is produced as good as positble on the average farms under average conditions.

On account of the high cost of grain and feed, in short everything, the dalrymen feel that they must make the usual winter raise, or quit business. Two dairymen already have gone out of business.

Commencing November 15 th we will give 12 pirt tickets for 50 cents. St11l at that price, considering the composition of milk, it is the cheapest and most wholesome focd offered on the market of St. Charles. Dalrymen."

According to agreement, a meeting called by the Board of Health, supposedly to Include the Bcard, members of the Chamber of Commerce, and the farm adviscr, was held on the night of November 13th. The dairymen were invited and urged to attend. There actually appeared at the meeting, two members of the Bcard of Health, three from the Chamber of Comnerce, a reporter, end five dalrymen. 
It had been our purpose at this meeting to make suggesticns concerning a method of reform. It should be explained at this point that the Board of Health was not made up of college graduates, doctors, or health experts, nor were they chosen for their qualities of leadership. They were good, consctentlous business men, who wculd gladly do anything they could for their community. It was not wholly a surprise, therefore, to find them and the mayor, who was chalrman of the Board, lacking at this meeting.

We were firmly of the belief that a compalgn of the kind to be suggested should be carried on by the people, with our adrice and ald, but not by us. For these reasons, having got together the leading dafrymen (Nos. $1,5,6$, and 7 ) and a few of the men interested in the consumers problem, they were told in an informal talk, of their milk situation. There was danger of losing all rold on the dalrymen as a result of cur activities with the consumers and council. The neutral positicn which we attempted to maintain was explained to both. The rights of the consumer in the control of the milk supply was described to the dalrymen. Those representing the consumer were in turn edvised of the rights of the dairymen. The meeting broke up with no action having been taken, but with a mutual understanding existing between the leaders of the two contending parties. 
This meeting was likewise reported by the Presi. On the 2and of November the accompanying letter was received:

"Dear Sir:$11 / 20 / 16$

The St. Charles Dalrymen's Association has instructed their secretary to write a letter to you, bringing cut the following points.

There again appeared in the Banner News an article that was anything but incourifing to the dairymen, especially at this time. Both articles written in this paper can be taken ir two ways, and as it is the nature of human beings the majority of us think cnly of the worse part. Unfortunately this seems to be the case with many of cur customers. Therefor many curious questicns are asked. It seems as though the majcrity of the consumers thirk that the dalryman is elther a fool or a crock. Some dalrymen blalm you directly others indirectly for those articles. The latter saying that they know that you did not publish them but if you had not come down here the articles would never have been 
published, and if, as you have said that article did not tell the whole story we believe that it is your duity to give the facts as they are. About the way you gave them at the time the Board of Health met with some of the dairymen. By so doing you would save the dairymen much time needed to explaining to the individual customer, and a great deal of unpleasentness. We therefore kirdly request you to publish the facts and explain all statements thcroughly or at least see to it so no articles of that kind are published in the paper any more.

We are only sorry that your efforts are crowed with such little success.

We will be glad to see you socn again,

$$
\text { Respectfully yours, }
$$

The St. Charles Dalrymen Association."

In accordance with the request in the above letter, a report was drawn up, including the recommendaticns which were to have been presented at the meeting of the Board of Health, on November 13th. Coples of 
this report were sent to the Dairymen's Asscciation, Chamber of Commerce, Women's Civic Cilub, Board of Health, farm advisor, and editor of the Banner News. The report appeared in full in the December 5 th is sue of the News.

\section{REPORT OF CONDITION OF ST. CHARLFS MIIK SUPPIY,} WITH RECOMNENDATIONS FOR ITS IMPROVENINTT.

"In accordance with several requests for a report of an investigation of the milk supply of St. Charles, Missourl, made during the past summer and fall by the Missouri Agricultural Fxtension Service, the following report is given. It should be borne in mind that this investigation covered the summer and fall months only, the conditions in mid-winter not having been determined.

"Cows milk is indispensible in the artificiel feedirg of Infants and of the greatest importance in the diet of ell children. Not only is it cf great necessity for child feeding, but it is one of the cheapest sources of muscle and brain building material and can and should take the place of expensive meats in many meals. One quart of milk has a food value equivalent to three-fourths of a pound of beef or elght eggs. Because of this 
universal need and use of milk it becomes a matter of the greatest importance to any community to see that the milk sc used is pure and wholesome. "Milk, as it comes from the healthy cow, is a.s pure as the sculs of the innocent children who will eventually use it. It is the dirt that falls to the pall from the dirty cow, the germs of disease and putrefaction, which enter the milk cans from the streets or contaminated water supplies, the warm temperatures at which the milk is held which is responsible for the impurity and unwholescmeness of milk.

NEC,ESSARY CONDITIONS FOR OBTAINING A GOOD MILK SUPPIY.

"The conditions necessary for obtaining a good milk supply are:- First, a consumirg public acquainted with the importance of good milk and of the requirements of good milk;

Second, dalrymen acqualnted with the methods of pure milk production with a busiress on a paying bas1s;

Third, 8. reasonable milk crdinance capable of beirg enforced which should require the conditions necessary for a safe milk supply. Such an ordinance wlll protect the honest, conscientious dalryman and will force 
the unscrupulous into line. Success in obtairing a high grade of milk for any town depends upon the harmenious working out of these three conditions. These three necessary conditions are lacking to a great extent in St. Charles and are responsible for the sanitation of its milk supply.

"The public does not know the economy of milk in the diet nor the importance of it in the diet of children, else far more would be consumed. The public does not realize the dangers lying behind the pure whiteness of milk which is drawn from cows not known to $b \in$ free from tuberculosis, or which is not properly cooled before delivery. If the dangers of using milk poured from can to $p$ all and from pail to dish in the streets were realized, bottled milk would be in universal demand. "The dairymen do not realize the importance of the relationship between milk and the health of the children and others who consume it. Nelther do they realize that their poor livelihood is due to poor business methods; low producing cows--cows whose calves bring little or nothing; poor marketing conditions; poor feeding; and lack of cooperation between them. Fifteen to twenty dalrymen are trying to supply the small amount of whole mflk used by the town, while the dalrymen of Illinols are supplying the majority of the ice cream 
and are even sendirg to St. Charles hundreds cf crates of cordensed milk annually because the public finds it of superior quality to the raw milk supplied by the local dairymen.

"Successul remedies for any situation can only be found by studying the real condition to be remedied and locating the true causes of that condition.

\section{CONDITIONS.}

"Following is a brief statement of the conditicn of the milk supply of St. Charles.

1. Milk is drawn from cows not known to be free from tuberculosis in all dalry herds but one. (To my knowledge one dairyman only has had his herd tested and had tubercular animals remcred.) The dairymen do not use cows which show any external signs of disease, however.

2. Milk is delivered promptly, so that it is fresh when delivered--a distinct advantage over the milk of the large clities.

3. Wilk is cocled by well and spring water which in summer months is not cold enough to prevent the rapid multiplication of bacteria, which quickly sour the milk. In winter, if the same method of cooling is used, however, the milk maj be kept cold enourh. 
4. The cows in all but two or three of the dairies are housed in barns so constructed that it is very difficult to keep them clean; this will be especially true in winter, when the cows are kept indoors most of the time.

5. In no case were the small topped milking buckets in use, which so greatly ald in preventing the entrance of dirt into the milk during milking. Two dalrymen to my knowledge have provided themselves with these buckets since the investigation began.

6. The Ereat majority of the milk of St. Charles is delivered loose from cans, which incresse by many times the chances for contamination of the milk. The cans are not opened once on the street, but five to ten tines. Each gallon or two of milk must be dipped or poured from the can and separately measured out to the consumer. It should be measured out in a clean room on the farm and put in closed bottles, which are opened only by the consumer. The dangers from the present antiquated method of delivery cannot be overestimated.

7. The accompanying table (Table VI. given above) shows the results of fat tests and bacterla counts, the number of bacteria varying in accordance with the cleanliness of production, age, and temperature of the milk. A glance at the fat tests shows that the 
average test is normal; but that, due to the method of distribution, the per cent of fat varies in almost every gallon of milk taken from the can, sometimes being very high, at others being very low.

The number of bacteria is typical of milk in warm weather where ice is not used in cooling, when extra precautions are not taken to prevent dirt from entering the milk, and where the utensils are not sterilized before using. The wide variation in the per cent of fat, together with the changes brought about by the immense number of bacteria, would render the milk of doubtful value in infant feeding.

\section{RESPONSIBIIITY FOR CONDITIONS.}

"The blame for the condition of the supply cannot fairly be put upon any one or any one class of people. Presumably, the 1mportance of the question has never been brought to the attention of the consumers and the dairymen have come into the business in response to the demand for milk of the present quality.

"If, however, the condition as found is correct, as we believe it is, and if the true causes of this condition have been determined, then the respons1bility for correcting tils condition will rest upon those organizations of the men and women of the city which 
have become acquainted with the condition and have the interest of the community at heart; the Board of Health, chosen by the people to protect their health and the health of their children; and upon the officials entrusted with the enacting and enforcing of laws necessary to regulate the affairs of the community.

"These organizaticns have declared their interest in the welfare of their community. The Board of Health has indicated its desire to use its influence in solving the problen; the public officials have expressed their desire to use their lawmaking and enforcing power, upon recelving sufficient backing and interest on the part of the people. All that remains is for these groups to clearly appreciate the Importance of the condition, to satisfy themselves as to the cause of this condition and then to take steps to remove these causes.

C.AUSFS OF LOW GRADE MILK.

"The underlying causes of the low grade milk of St. Charles we belleve to be mainly two: First, the lack of uniform demand for milk of the best quality, which is probably due to the fact that the people do not appreclate the value of milk, its importance to health, and the resl requirements of good milk. Second, the dalrymen do not make sufficient money from their 
business as organized at present to enable them to change their methods very materially, without increasing the price of milk.

\section{METHODS OF REFORM SUGGESTFD.}

"The methods of reform then should be directed mainly along two lines. First, the informing of the public of the true value of milk; the importance of safeguarding milk; the real definition of good market milk. In other words, a widespread demand must be made for good milk.

"Second, far reaching steps must be taken to better the dairying condition about st. Charles. The dairymen should be convinced that there are ways to make more money at no greater expense of energy, if they w111 accept the experience of dairymen of other dairy communities. They must have pointed out to them the ineconomy of feeding low producing cows, and ways of securing better cows in the cheapest manner; the value of silage and the balanced ration. They must be aided in securing a wider and better market for their product. "Finally, there should be framed an ordinance, the requirements of which would protect the dalryman desirous of improving, agalnst the competition of those who would not come up to the requirements. 
"To accomplish the first, the people who are most interested should make an effort to get the people out to a public talk on the question. They should solicit the ald of the newspapers in printing articles pertaining to the subject. In this work the Missouri Dairy and Agricultural Extension Departments will be only too glad to help as far as their funds will permit.

"To accomplish the second, the business men and the county farn advisor should first study the dairymen's needs, which are, better stock, better methods of feeding, and better methods of marketing. Second, ald the dafrymen in securing these things. They can be of most ald possibly in increasing and bettering their market. There is a good possibility of establishing a market milk, ice cream and creamery plant, which will supply all of St. Charles and maybe part of St. Louis as well. It will not only ald in securing a larger market for the dalrymen, but will lessen the cost of distribution and make it possible to bottle and pasteurize the milk. Such a plant could be of the greatest service to the dairymen if it could be organized on a cooperative plan. But even privately owned and operated, if successful, it would lead to more and better dairying in the county.

Weetings of the dairymen should also be held for the purpose of discussing problems of feeding, 
breeding and sanitary milk production and distribution.

"The dairymen should first be appealed to in any case. They are producing the milk and have it in their power to produce or stop, as they please, and in the long run will determine the quality of the milk. A change of methods is being asked for, which means increased expense to them. To require these changes without alding them in reducing their cost of doing business or increasing their market, is unreasonable and unjust, unless they refuse all such offers of help. The dalrymen on the right side means half the battle won. In the event the dalrymen prefer not to change or look for better methods, which is very unlikely, then the people of st. Charles can, without doing the least injustice, require certain changes to be made, which will result in those dalrymen who cannot or do not wish to answer the requirements, leaving the business to those who can and wish to furnish the higher grade of milk." It was the aim of these efforts at educating and organizing the social forces of the community, to renove as far as posslble the social causes for a poor milk supply, which, as above mentioned, consisted mainly in the lack of an intelligent and insistent demand for good milk, with fallure to pay for better mlik. The following discussion will bring out the results of the whole movement upon the milk situation of st. Charles. 
VI. DISCUSSION OF RESULTS.

The results of the movement will be discussed from the standpoint of the dairymen, the consumers, the public officials and business men, and the quality of the milk itself. The study began with the quality of the milk and went from that to a study of the causes of the bad conditions found. In order to obtain a better supply of milk, the causes for the poor conditions had to be removed. It would naturaliy follow that the first changes to be noted would be in the causative agents, and that the final change would be in the quality of the milk itself.

A decided change in the cause factors is claimed as a result of the reform. Briefly, the causes were found to exist in the unintelligent demand for milk among the consumers, the lgnorance and poor economic status of the dafrymen, and the lack of responstbility and control on the part of the c1ty.

Dairymen: The most Important change is to be found in the dairymen themselves. As previously noted, two of the worst dairies were eliminated and a third small dalry has closed. The largest of these closed because of a loss of trade, resulting from the agitation 
brought about by this investigation. The most encouragIng change in the dalrymen, however, has been in their attitude toward the milk problem and toward each other. The dalrymen's association, which was formed for the purpose of protecting their interests from unfair restrictions which might be made by the town, and of securing an advanced price for their product, was an outgrowth of suggestions and encouragement given by us. It resulted in securing a material increase in the price of milk; in a premlum for bottled milk over loose milk; and in a cooperative organization headed by a well read, intelligent dairyman, who alms to bring better cattle and better methods and equipnent to the members. The dalrymen are not only organized for a good purpose, but they are ready to cooperate with the college and experiment station in any effort to better their conditions. The dalrymen, as a whole, have had the essentials of clean milk production pointed out to them, which has resulted in the use of covered palls by two of the dairymen, the tuberculin testing of three herds, with a promise of more, and in the serious consideration by the largest dairy of turning its whole trade into bottled milk. There exists a virtual agreement with the same dairyman to cooperate with the university in making his a demonstration farm. 
Consumers: The only evidence of change in the consumers of St. Charles is the fact that they have shifted their trade from some of the bad dairies to the better ones. Dairyman No. 3 was forced out of business as a result. The trade of No. I has risen from 45 to 60 gallons of milk per day. That they read the newspaper accounts of the dairy meetings and noted the reports of the milk analyses was evidenced by the letter from the dalrymen's association, which has been referred to above. A special point was made in preparing all of these newspaper accounts to make them of educational value to the consumers. This can be seen from the report which was printed in the December 5 th issue of the Banner News.

Public Officials and Business Men: The attempt to secure the passage of an ordinance which would bring about a measure of control of the milk supply falled completely. The following quotation from a letter from the farm advisor on December 7 th indicates the attitude of the Board of Health and mayor of St. Charles:

"I saw the Mayor yesterday and asked If the Board of Health had taken any steps toward continuing the investigations and giving any further publicity to the movement and he replied 
that he knew of nothing that was being done and further stated that the Board of Health did not seem to be interested, and that inasmuch as they found no fault with the health of the community, he could not see where they had any reason to stir up any trouble.

That appears to be the stand he has taken in the matter and a consultation with Willbrand and Hutton resulted in the decision that the matter would better rest a little in preference to trying to urge up any action on the part of the Bcard of Health for the reason that they might beccme pronounced against any movement whatever."

Tho the fallure of the council and the Board of Health to take decided action in regard to the milk situation had little to do with a change of officials, a complete change was brought about in the April election. The following from the farm advisor on March 31 t gives rise to the belief that the change which followed, will make easier an effort to secure some control in the future over the milk supply: 
"The coming electicn of city officials which takes place Tuesday will quite probably change the personnel of the Bcard of Heal th-......

-...-. I might say that there will, in all probablitity, be a new mayor as well as city council, and the matter will have to be brought to their attention, and I am almost sure that we can get some better ccoperation than we had with the former parties who have been in power."

As will be noticed in the "Report of Cond1tions of the St. Charles Milk Supply" given above, the farm \&dviscr and business men were strongly urged to aid in this movement by helping the dalrymen to better their conditions. No attempt is here made to claim credit for the activities of the advisor and the chamber of commerce in their dalry efforts. It had been the plan of the chamber to eventually develop the dalry interests of the county. However, the presence of the dafrymen's association, and the opportunity it afforded to make a beginning in this work, stimulated the chamber of Commerce and the farm adrisor to start a dalry development program, which has as 1ts alm the bringing of pure bred cattle into the comminity, with the attendant 
discussion of, and awakening of interest in dalry problems. Recause of these activities, two men are consldering the establishment of a local creamery. The development of dairying in the neighborhood of St. Charles has been started and will continue.

The Milk of St. Charles: An examination of the few tests of milk made in January show the milk to be of a first grade quality. The per cent cf fat is normal in all but one case; the bacterial counts are low, and the temperatures are low. The tests were too few to draw any definite conclusions from them. The temperature of the air at the time was 55 degrees, and that of the cooling water was probably lower. The low bacterial counts are due in large part to the low temperatures maintained. The chief change in the milk itself is in the fact that 41 per cent of it now comes from tuberculir tested cows, whereas only 6.6 per cent came from such cows in summer and fall; and in the elimination of 35 gallons of milk a day from two dalries whose milk was \& constant source of danger to 1 ts consumers. 
Summary: To summarize the results of the investigation, it is believed (1) that the varicus factors necessary for the cbtainment of a pure milk supply have been brought to a realization of their part in the problem; (2) that if a practical methcd of control can be suggested, the time is rife for its pasage and enfcrcement and use; (3) that the actual lowering of bacterial counts, stardardizing of the per cent of fat and solide, protection frcm disease--betterment of the quality of the milk itself, in other words--can come cnly thru the careful supervision of the milk supply Which must be carried on in large part by the local Board of Health. 
Part of the Agricultural rolleges

And Experiment Stationg in Milk Control Work.

As a result of the foregoing efforts in this field of endearor, it would seen that the colleges can properly instigate milk reform, and $\mathrm{school}$ and prepare the necessary agencies in the local community to a sense of their powers in milk control work. Education of the producer, consumer, and public officials and voters in the importance of pure milk and the need of cooperation and vigilance, constitutes the chlef problem in bettering a milk supply. We are forced to the belief that the small towns need help in the control of this sort of a problem. A practical nethod of laboratory and inspection control which could be carried on by the local Board of Health and st11l be guided and aided by the Fxperiment Station has been concelved by the writer and will be discussed in the following section. 


\section{PART II.}

Laboratory Control of the Milk Supply of the Small City.

An Application of the Breed Method of

Direct Microscopic Enumeration of Bacteria in Milk

Preserved with Formalin. 


\section{CONTROL-- \\ APPIIC,ATION OF BREED METHOD OF COUNTING BACTERIA.}

In the sanitary control of milk supplies, the bacterial count is generally accepted to be the truest indication of the sanitary quality of raw milk. It bears a direct relation to the degree of cleanliness observed in the production and care of the milk, the temperature at which it is kept, and its age.

The counting of bacteria in milk can be done accurately only by a well trained laboratory worker who is nore or less of a specialist along this line. The average small town is unable at present to secure a bacteriological control of its milk supply because of the expense of employing a laboratory worker and fitting up a laboratory. There is not sufficient work to be done by such a man in the small community.

Before the small milk supply can be successfully controlled, there must be found a method of bacteriological analysis of milk which is practical for the snall town.

The direct microscopic enumeration of bacteria in milk seems to the writer to offer some interesting possibilities of adaptation to the small milk supply. Its accuracy in the enumeration of bacteria in fresh 
milk has been sufficiently proved by Breed and the New York Milk Commission, as shown by the following quotation from their report by $H$. W. Conn: "The direct microscopical examination of milk smears by the Breed method will classify raw milk into grades $A, B$, and $C$ with about the same accuracy and much more quickly than the plate method of bacteriological analysis will do." It reveals the number of individual bacteria, both dead and alive and the groups. It will give a count of the leucocytes in milk and will show the presence of streptococci. If dead bacteria will be revealed by this method, then it seems plausible that a bacterial count could be made of milk preserved in formalin. If this should prove to be the case, this method of counting bacteria is subject to a very wide application.

It suggests for instance the possibility of securing a bacteriological control of the small milk supply without the expense to the town of a laboratory and a bacteriologist. The samples might be collected by a local agent, preserved with formalin and shipped to the Experiment Station where the bacterial count can be made. One central laboratory could thus make the tests of milk from all the small towns of the state. The expense of the testing could be divided among the Individual towns. A person who is capable of taking 
the temperature and representative samples of milk from the dairyman would do all the work that would be required in the town. The sample bottles containing the preservative could be prepared at the laboratory and sent in sufficient numbers to the towns. If the bacterial count could be thus determined, a complete analysis of the milk would be possible. Tests for butter fat, water and solfds not fat can all be made from a preserved sample. A test for preservative is perhaps the only test ordinarily applied to milk which could not be carried out with such a sample.

\section{HISTORIC,AI.}

The enumeration of bacteria in liquid cultures by means of the direct microscopic count has been used in a variety of ways ever since the time of Iister, Koch and Pasteur in $1877 .^{(39)}$ It was first used to determine the approximate number of bacteria in suspension for use as a guide to the proper dilution necessary for plate counting. The application of the method to actial counting was made originally to sewage and water analyses by Winterberg, Klein, $(38)$ and Heberwerth. (39) In the early use of the method, the substance under examination was first centrifuged, as in the counting 
cf blood cells. Klein and Winslow $(26 \& 27)$ in 1903 worked out methods of staining their material by the addition of methylene blue to the suspension and the drying of definite portions on clean cover glasses of known size.

The first application of this method to milk analysis was made by Dr. F. H. Slack (37) who noticed a relationship between the plate count of bacteria in milk and the number of bacteria in stained centrifuged samples which he was exanining for cell and streptococcus content.

The disadvantages of centrifuging samples of milk to determine the cell or bacterial content was pointed out in 1909 by Prescott and Breed (28) who published results of a method they had derised of determining the cell content of milk by the microscoplc method without centrifuging.

In 1911 the same authors published for the first time their use of this method in the counting of bacteria in milk.(36) Skar in 1912 and Rosa ${ }^{(39)}$ in 1913 used similar methods, differing chiefly in their method of staining which consisted of the addition of methylene blue to the milk before making the smears.

In 1914 Brew of the Geneva Experiment station published results of comparisons made at the station 
upon the microscopic count of milk by the Breed and the ordinary plate methods. ${ }^{(39)}$ His results indicate a fairly close relationship between the twc, in cases of milk of high bacterial counts. Where less than 10,000 bacterla per cubic centimeter were present by the plate count, the microscopic count showed forty-four times as many. He concludes that milk can be accurately graded into two grades including in the first, that milk in which there are over 100,000 bacteria per cubic centimeter, and in the other, milk with less than 100,000 per cubic centineter.

The United States Public Health Service published results of investigations made in New York of comparative tests of bacterlal counts by several methods used in four of the milk testing laboratories of the city. This represents the most extensive test yet made of the use of the Breed method of direct microscopic examination in comparison with the plate count. The committee making the investigation concludes that this method gives as accurate results in the grading of milk into three grades as the plate count when done by one trained in the use of the test. They graded the milk according to the bacterlal count as follows: (A) milk containing under 100,000 bacteria per cc.; (B) over 100,000 and under 1,000,000; (C) over 1,000,000. 
It has been pointed out by numerous investigators $(27 \& 39)$ that the microscopic count gives dead as well as living bacteria, although there is considerable doubt as to the length of time dead bacteria will take the analine dyes. For instance, Winslow and Wilcomb say, "We know, indeed, from study of higher crganisms that protoplasms after death degenerate and break up so that definite cell structures can no longer be made out, by treatment with analine dyes. " $(27)$ Under certain conditions, however, they show that the cells will remain unchanged for many hours. The following table 1llustrates the results of staining of dead $B$. subtilis. 
Table VIII.

Aqueous Solution of B. Subtilis Before and After Heating to 70-80 Degrees for 30 Minutes.

\begin{tabular}{|c|c|c|c|c|}
\hline TIme & : & Number Bacteria & $:$ & Number Bacteria \\
\hline & : & M1croscopic Count & : & Agar Plate Count \\
\hline Before Heating & : & $23,900,000$ & $:$ & $3,360,000$ \\
\hline $\begin{array}{c}\text { After Heating } \\
2 \text { Hours }\end{array}$ & $:$ & $23,000,000$ & $\begin{array}{l}\vdots \\
\vdots \\
:\end{array}$ & 19,000 \\
\hline After Heating & $:$ & $22,500,000$ & $\dot{0}$ & 000 \\
\hline $\begin{array}{c}4 \text { Hours } \\
\text { After Heating }\end{array}$ & $:$ & $26,900,000$ & $:$ & 000 \\
\hline $\begin{array}{c}6 \text { Hours } \\
\text { After Heating }\end{array}$ & $:$ & $20,000,000$ & $:$ & 000 \\
\hline $\begin{array}{l}24 \text { Hours } \\
\text { After Heating }\end{array}$ & : & $20,900,000$ & $:$ & 000 \\
\hline
\end{tabular}


The use of formaldehyde in preventing the development of bacteria in a sample of material to be analyzed by the microscoplc count was first used by Nueller, $(29$ \& 30$)$ who, adds formalin to the sample before precipitating the bacteria in the precipitate formed by addition of Ifquor ferri-oxy chlorati to his water s ample.

He made no tests to determine the length of time the dead bacteria would accept the stain.

That formalin will prevent the development of bacteria in milk when present in sufficient concentration has been proved by numerous investigators. Chester and $\mathrm{Braw}(35)$ of Delaware College of Agriculture report that formalin in the proportion of from 1 : 500 to 1 : 10,000 causes a reduction in the number of 11 ing cells in the first 24 hours. In weaker solutions of formalin the bacteria slowly increase.

The New York Experiment Station at Geneva has made the first practical use of this method of counting bacteria in milk control work. (34) They are at present grading milk from several local milk companies in Genera which hold contracts with dalrymen for milk, bought on basis of the bacterial count as shown by the microscopic method. They report entire satisfaction to all parties concerned. 
EXPER ININTAL WORK.

It was the purpose of the experiments described in the following, to determine whether the addition of formalin to milk will interfere with the successful erading of milk by preventing the staining of the bacteria after preservaticn for several days. If it should be shown that milk so preserved could be accurately graded according to the bacterial standards set by the New York Commission on Milk Standards, then the use of this methed ir grading of milk for the small town as above described, would be entirely practical. Micrcscopic counts were made of samples of whole milk of varying sanitary erades after which each sample was preserved in a closed container with formalin in the proportion of one part to 500. From two to five days later counts were made from each of the preserved samples with the following results: 
Table I.X.

Microscopic Count of Bacteria in Milk

Before and After Preservation by Formalin.

\begin{tabular}{|c|c|c|c|c|c|}
\hline$\frac{\text { Sample }}{\text { Old Milk }}$ & $\dot{0}$ & $\begin{array}{l}\text { efore Addin } \\
\text { Formalin } \\
\text { Number }\end{array}$ & $:$ & $\begin{array}{l}2 \text { days after ad } \\
\text { ding Formalin. } \\
\text { Number Bacteria }\end{array}$ & $\begin{array}{l}\text { :5 days after ad- } \\
: \text { ding Fcrualin. } \\
: \text { Number Bacteria }\end{array}$ \\
\hline & : & Bacteria & $\dot{:}$ & & $\begin{array}{l}: \text { Number Bacteria } \\
:\end{array}$ \\
\hline 1 & $\begin{array}{l}\text { : } \\
:\end{array}$ & 580,000 & $\begin{array}{l}: \\
:\end{array}$ & 612,000 & 183,000 \\
\hline 2 & $\begin{array}{l}: \\
:\end{array}$ & $4,986,000$ & : & $2,620,000$ & $1,638,000$ \\
\hline 3 & $\begin{array}{l}\text { : } \\
:\end{array}$ & $185,000,000$ & $\begin{array}{l}\text { : } \\
\text { : }\end{array}$ & $99,500,000$ & $155,400,000$ \\
\hline 4 & $\begin{array}{l}: \\
:\end{array}$ & $6,590,000$ & $\begin{array}{l}: \\
:\end{array}$ & $10,772,000$ & \\
\hline 5 & $\begin{array}{l}\text { : } \\
\text { : }\end{array}$ & $2,268,000$ & : & $1,320,000$ & \\
\hline 6 & $\begin{array}{l}\text { : } \\
:\end{array}$ & $1,572,000$ & : & $1,626,000$ & \\
\hline 7 & $\begin{array}{l}\text { : } \\
:\end{array}$ & $2,466,000$ & : & $2,094,000$ & $\begin{array}{l}\text { : } \\
:\end{array}$ \\
\hline 8 & $\begin{array}{l}: \\
: \\
\end{array}$ & $4,062,000$ & $\bullet^{\circ}$ & $1,968,000$ & $\begin{array}{l}: \\
: \\
:\end{array}$ \\
\hline
\end{tabular}




\section{Table IX. (continued)}

Microscopic Count of Bacteria in Milk Before and After Preservation by Formalin.

\begin{tabular}{|c|c|c|c|}
\hline Samples & $\begin{array}{l}\text { Before Adding } \\
\text { Formalin }\end{array}$ & $\bar{\vdots}$ & $\begin{array}{l}\text { Days after Addirg } \\
\text { Formalin }\end{array}$ \\
\hline Fresh Milk & Number Bacteria & $\bar{\vdots}$ & Number Bacteria. \\
\hline 9 & 48,000 & $\vdots$ & 12,000 \\
\hline 10 & 54,000 & $\vdots$ & 18,000 \\
\hline 11 & 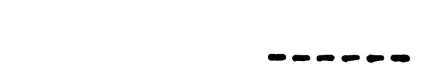 & $:$ & ---1 \\
\hline ? & & : & \\
\hline 12 & 48,000 & $\vdots$ & 120,000 \\
\hline 13 & 18,000 & : & 6,000 \\
\hline 14 & 6,000 & $:$ & $\cdots-$ \\
\hline 15 & $\ldots$ & $\vdots$ & 12,000 \\
\hline 16 & $-\cdots$ & $:$ & 6.000 \\
\hline : & & $\vdots$ & \\
\hline 17 & $-\cdots-$ & $\vdots$ & $\cdots--$ \\
\hline 18 & 18,000 & $\vdots$ & 12,000 \\
\hline 19 & $-\infty-\infty$ & $\vdots$ & 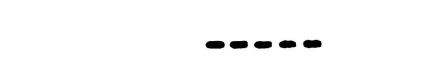 \\
\hline 20 & 12,000 & $\vdots$ &.--- \\
\hline 21 & $-\cdots$ & $\vdots$ & -..-- \\
\hline 29 & 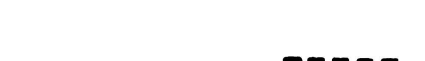 & : & \\
\hline $2 \alpha$ & $x^{-1}$ & $\vdots$ & $\cdots--$ \\
\hline 23 & $\cdots-$ & : & -... \\
\hline 24 & $-\infty-$ & . & -2 \\
\hline : & & • & \\
\hline 25 & $-\cdots$ & : & 6,000 \\
\hline 26 & 18,000 & $:$ & 6,000 \\
\hline
\end{tabular}




\section{Table IX. (rontinued)}

Microscopic Count of Bacterla in Milk Before and After Preservation by Formalin.

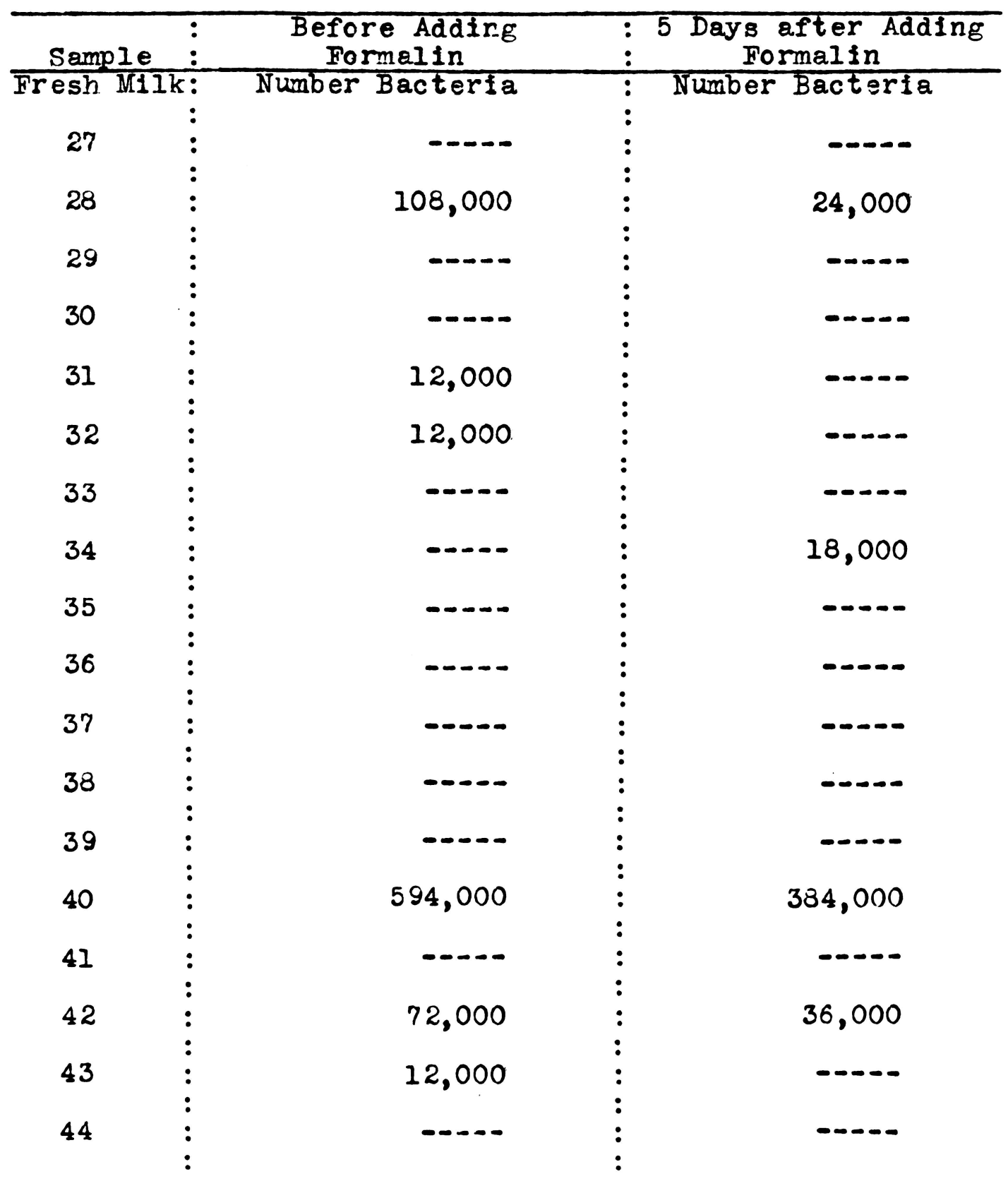


Table IX. (Continued)

Microscopic Count of Bacteria in Milk Before and After Preservation by Formalin.

\begin{tabular}{|c|c|c|c|}
\hline$\frac{\text { Sample }}{\text { Fresh M1lk: }}$ & $\begin{array}{l}\text { Before Adding } \\
\text { Formalin } \\
\text { Number Bacteria }\end{array}$ & 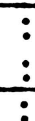 & $\begin{array}{l}\text { Days after Adding } \\
\text { Formalin } \\
\text { Number Bacteria }\end{array}$ \\
\hline - & & • & \\
\hline 45 & $1,158,000$ & $:$ & 300,000 \\
\hline 46 & 12,000 & : & 18,000 \\
\hline 47 & 12,000 & $:$ & $-\ldots$ \\
\hline 48 & $\cdots-\cdots$ & $:$ & $-\cdots$ \\
\hline 49 & 54,000 & $:$ & $\cdots$ \\
\hline 50 & $-\ldots$ & : & 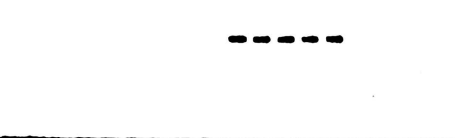 \\
\hline
\end{tabular}




\section{Discussion of Results.}

A brief discussion of the use of the bacterial count in the grading of milk will assist in making clear the significance of the conclusions drawn from the above data. Milk is usually graded into three grades which findicate the degree of cleanliness observed and the temperature regulation in the handling of the milk. Grade A, which according to the standards set by the Commission on Milk Standards appointed by the New York Milk Committee, ${ }^{(4 l)}$ includes all milk containing under 100,000 bacteria per cubic centimeter, is milk of a high quality which has been produced under clean conditions and has been kept cold. Grade $B$, which includes milk containing between 100,000 and $1,000,000$ bacteria per cubic centimeter, is milk which, tho not to be condemed for raw consumption, has not been produced with the greatest degree of care. Grade C, containing over 1,000,000 bacteria per cubic centimeter, is milk so carelessly handled that it is generally considered to be unfit for consumption in the raw state.

The Ifne of distinction between these different grades is very indefinite. The unavoldable error in the counting of bacteria by any method yet devised is such that it is impossible to say for instance, that 
milk containing only 90,000 bacteria per cublc centimeter is any better than milk containing 110,000 . But the methods in use are sufficiently accurate to justify one In the conclusion that there is a marked difference in the sanitary quality of milk containing close to a million bacteria per cubic centimeter and milk containIng considerably under 100,000.

Examination of the data given above shows that in all but three cases the milk would be put in the same grade whether the count were made before or after preservation considering the grades to be as defined above: Grade A, under 100,000 bacteria per cubic centimeter; Grade B, under 1,000,000 and above 100,000; Grade C, over 1,000,000. The fact that some samples varied as much as 30,000 does not at all interfere with the successful grading of the milk. In the case of the fresh milk where samples are reported as containing no bacteria, this simply means that the number is under 6,000 , as 6,000 is the factor by which each bacterium on the microscopic field was multiplied, in arriving at the total number per cublc centimeter.

It is not belleved that the number of samples tested is sufficient to prove beyond doubt that formalin does not destroy the ability of some bacteria to accept analine dyes after two to five days preservation, but 
it does at least clearly indicate that such is the case.

In the light of this evidence, it would seem to the writer that the laboratory control of the small milk supply could be easily and practically carried on by a central state laboratory where preserved samples could be sent for analysis. 


\section{BIBLIOGR APFY.}

1. Merrit, E. "Production and Consumption of Dairy Products:" U.S.Dept. Agr., Bulletin No. 177.

2. Mcrollum, E.V., Simmonds, N., Pitz, W. "The Relaticn of the Unidentified Factors, the Fat-soluble $A$ and the Water-soluble $B$ of the Diet to Growth Promoting Properties of Milk." Jour. Blo. Chem. Vol. 27, p. 23.

3. Mcrollum, E.V. "Fissential Factors in a Successful Diet." N.Y.Jour. Med. Vol. 103.

4. Sparge, J. "Common Sense of the Milk Question." p. 17, Edition 1. New York, MacMilian Company.

5. Same as 4 p. 232 .

6. Report "Finglish Royal Commisston on Relation 1910 of Human and Animal Diseases."

7. Trask, J.T. Milk as a Cause of Epldemics of Typhoid Fever, Scarlet Fever, and Diphtheria." U.S.Public Health and Martne Hospital Service, Bulletin No. 56, p.25.

8. Same as 4 p. 120 .

9. Whitaker, G.M. "Score Card System of Dairy Inspecticn. U.S.Dept. Agr., Bur. An. Ind. Circular 199.

10. Blue, R. "Bacterlologlcal Standarda for Milk." 1914 U.S.Pub.Health Service. Rept. No. 192. 
11. Pearson, R.A. "Market Milk: A Plan for Its Improvement." From 17 An. Rept. U.S. Dept. Agri. Bur. Animal Industry.

12. North, C.F. "North's Milk System." 30 Church St., New York City.

13. Rosenau, J.M. "The Milk Questicn."

1912 p. 138, Edi. 1. Bostor and New York. Houghton Miffin Company.

14. Kelly, F. Mertified Milk Commissions and Certi1913 fied Milk." U.S.Dept. Agr. Bul. No. I.

15. Proceedings Tenth An. Conference American Assn. 1916 Medical Milk Commissions. Cincinnati, 0 . Abington Press.

16. Murray, J.I. "The Pasteurization Question." 1917 Vol. LIII., No. 4, Hoard's Dalryman.

17. Trueman, J.N. Milk Supply of Chicago and Twenty1907 six Other Cities." U.Ill. Agr. Frp.Sta. Bul. No. 120.

18. Alvord, H.F., Pearson, R. A. MM1lk Supply of Two 1903 Hundred Cities and Towns." U.S.Dept.Agr. Bur.An.Ind. Bul. No. 46.

19. Doane, C.F. Milk Supply of Twenty-nine Southern 1905 Cities. U.S.Dept.Agr. Bur. An.Ind. Bul. No. 70.

20. Whitaker, G.M. Milk Supply of Boston, New York, 1905 and Philadelphia. U.S.Dept.Agr. Bur. An. Ind. Bul. No.81.

21. Whitaker, G.M. Milk Supply of Chicago and 1911 Washirgton." U.S.Dept.Aer. Bur. An. Ind. Bul. No.138.

22. Bitting, A.W. "Producticn and Delivery of Milk in 1901 Cities. Ind.Agr. Fxp.Sta.Bul. No. 89. 
23. Hammer, B.W., Hauser, A.J. "Studies on Market Milk 1916 in Iowa." Iowa State Agr.Col. Bul. No. 164.

24. Harding, H. A. "Publiclty and Payment Based on 1911 Quality as Factors in. Improving a City Milk Supply." N.Y.A.gr. Frp. Sta. Geneva, N.Y. Bul.337. 25. Harding, H. A. Brew, J.D. "Financial Stimulus in N.Y.Agr.Fxp.Sta.Geneva, N.Y. Bul. 363.

26. Winslow, C.E. A. "The Number of Bacteria in Sewage 1905 and Sewage Effluents Determined by Plating upon Different Media and by a New Method of Direct Microscopical Enumeration." Jour.Inf.D1s., Suppl. 1:209-228.

27. Winslow, C-E. A., Willcomb. "Tests for a Method of 1905 Direct Microscoplcal Fnumeraticn of Bacteria." Jour.Inf.Diseases, Suppl. 1:273.

28. Prescott, S.C., Breed, R.S. "The Determinaticn of 1911 the Number of Body Cells in Milk by a Direct Method." Jour.Inf. Dis., 7:632-640.

29. Miller, P.T. Meber eine neue, Raschbarbeitende $191 \approx$ Methcde der Bakteriologischen Wasseruntersuchung und thre Anwendung auf die Prufung, von Brunnen und Filterwerken." Arch. FyE., 75:189-223.

30. Muller, P.T. "Ueber melne Schnellmethode der 1914 Bakteriolog1sch $\in$ Wasseruntersuchung." Arch. Hyg., 82:57-75. 
31. Hesse, E. NUeber Paul Th. Mullers Schnellmethode 1914 der Baktericlogischen Wasseruntersuchung." Arch. Hyg., 83: 327-349.

32. Goodrich, G.W. "Comparison of the Plating and 1914 Microscopical Methods in the Bactericicgical Fxaminaticn of Milk." Jour.Inf.Dis. 14: 512-519. 33. Conn, H.W. "Standards for Determining the Purity
1915 U.S.Public Health Service, Reprint No. 295.

34. Breed, R.S., Brew, J.D. "Counting Bacteria by 1916 Means of the Microscope."

N.Y.Agr. Fxp.Sta. Geneva, N.Y.Tech. Bul. 49. 35. Chester, F.D., Brown, T.R. "Acticn of Formaldehyde
1905
in Preservaticn of M1lk." Delaware Agr. Exp.Sta. Bul. No. 71.

36. Breed, R.S. "The Determinaticn of the Number of 1911

Bacteria in Milk by Direct Microscopical Examination."

Centbl.Bakt., Abt. 11.30: 337-340.

37. Slack, F.H. "Die Mikroskoptsche Schatzung der 1906 Bakterten in der Milch."

Centbl. Bakt., Abt. 11, 16: 537-538.

38. Kle1n, Alex. "Fine neue Mikroskopische Zthlungs1900 methode der Bakterien."

Centbl. Bakt., A.bt. 1, 27: 834-835.

39. Brew, J.D.

"A Comparison of the Microscopical Methed and the Plate Method of counting Bacteria in Milk."

N.Y. Agr. Exp.Sta., Geneva,N.Y. Bul. No. 373. 
40. Allen, R.McD. "Milk Supply of Kentucky--Lcuisville." 1908 Kentucky Agr. Fro.Sta. Bul. No. 134.

41. Report

Commissicn on Milk Standards Appointed 1913 by New York Milk Committee.

U.S.Pub.Health Service. Reprint No.141.

;0; 


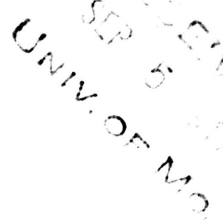

ACKNOWLFDG FIMFNT

The author wishes to express his appreclation to C. H. Fckles, Professor of Dafry Husbandry, University of Missourt, for his helpful suggesticns and adrice in the preparaticn of this paper. 


\section{$378.7 \mathrm{M7l}$}

XW495

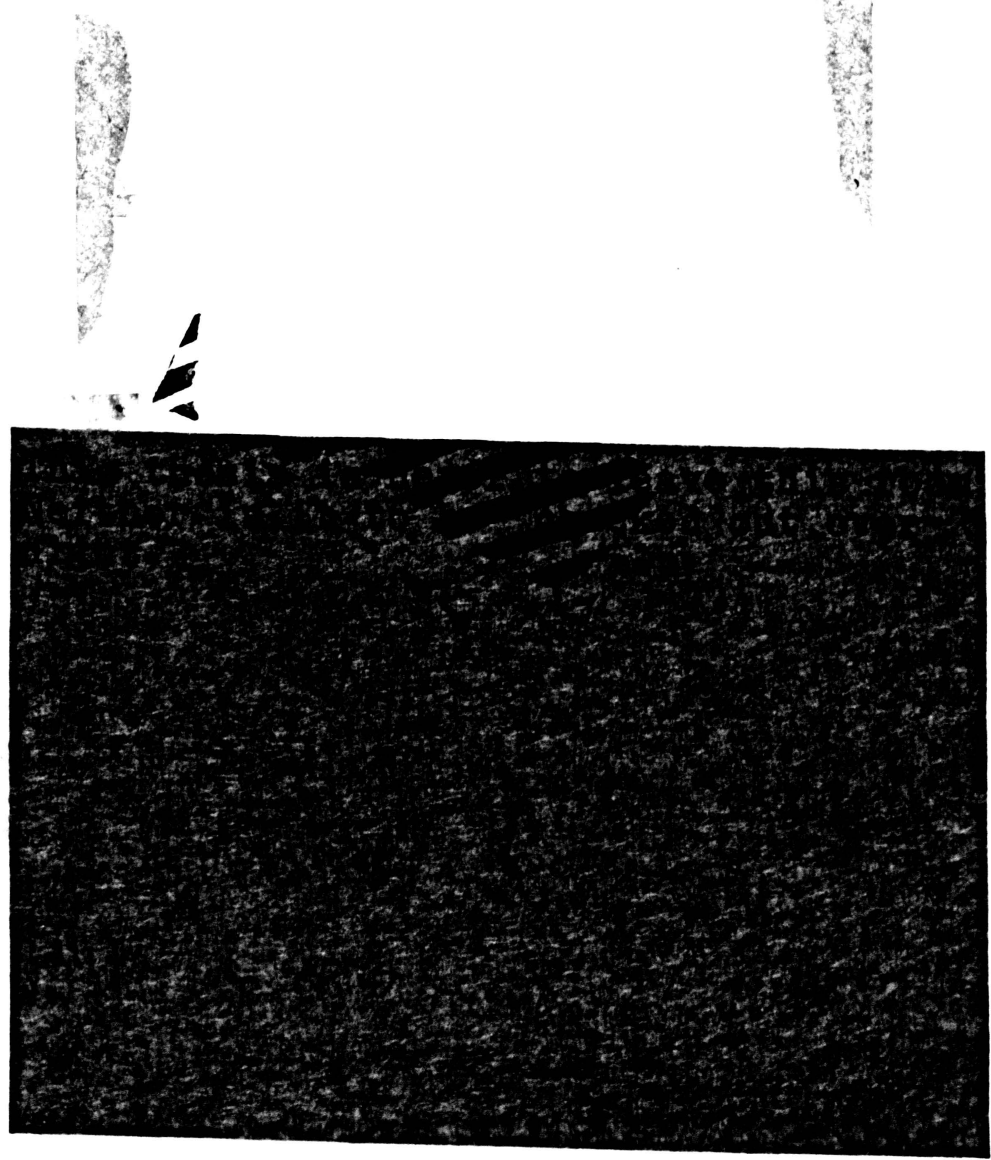


MU Libraries

Werner 1917 specsheet, $t x t$

University of Mi ssouri--Col umbia

MU Theses and Dissertations (Pre-1920)

Local identifier

Capture information

Date captured

Scanner manufacturer

Scanner model

Scanning system software

Optical resolution

Color settings

File types

Source information

For mat

Content type

Source ID

Notes
Werner 1917

20170203

Zeutschel

OS 15000

Omniscan v.12.8 SR2 (2675)

$600 \mathrm{dpi}$

grayscale, 8 bit

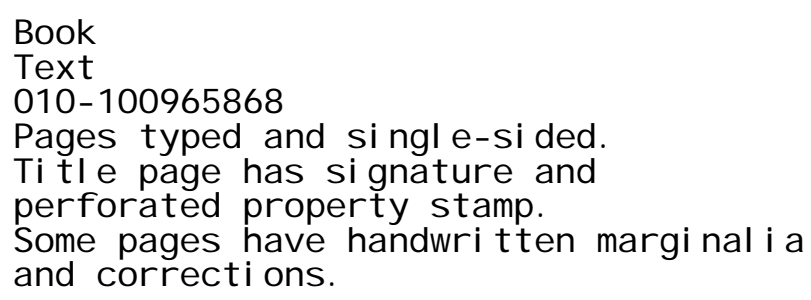

$010-100965868$

Pages typed and single-sided.

Title page has signature and

perforated property stamp.

Some pages have handwritten marginalia and corrections.

Derivatives - Access copy

Compression

Editing sof tware

Resolution

Color

File types

Notes

Tiff compressed with LZW before conversion to pdf Adobe Photoshop CS5

$600 \mathrm{dpi}$

Grayscale

$p d f$

Grayscale pages cropped, canvassed, and i mages brightened.

Bl ank pages removed. 